\title{
Prevention of Significant
Deterioration Significant
Deterioration Application for Approval to
Construct SP-100 Ground
Engineering
System Test Site Ground
Engineering
System Test Site Ground
Engineering
System Test Site

\section{TO NOT RILROFILM \\ COVER}

United States
Department of Energy
Richland, Washington

(a) 


\section{DISCLAIMER}

This report was prepared as an account of work sponsored by an agency of the United States Government. Neither the United States Government nor any agency Thereof, nor any of their employees, makes any warranty, express or implied, or assumes any legal liability or responsibility for the accuracy, completeness, or usefulness of any information, apparatus, product, or process disclosed, or represents that its use would not infringe privately owned rights. Reference herein to any specific commercial product, process, or service by trade name, trademark, manufacturer, or otherwise does not necessarily constitute or imply its endorsement, recommendation, or favoring by the United States Government or any agency thereof. The views and opinions of authors expressed herein do not necessarily state or reflect those of the United States Government or any agency thereof. 


\section{DISCLAIMER}

Portions of this document may be illegible in electronic image products. Images are produced from the best available original document. 

DOE/RL- $-90-14$

DE9 $0 \quad 007986$

\section{Prevention of Significant}

Deterioration Application for

Approval to Construct SP-100

Ground Engineering System

Test Site

Date Published

April 1990

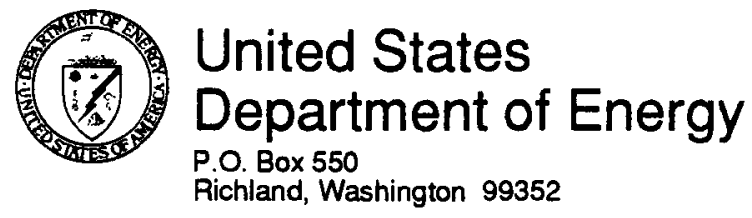


DOE/RL-90-14

This page intentionally left blank. 


\section{CONTENTS}

1.0 PROJECT LOCATION . . . . . . . . . . . . . . . . 5

2.0 PROCESS DESCRIPTION . . . . . . . . . . . . . . . . . 5

2.1 SOURCES OF EMISSIONS ................. 14

3.0 DESIGN AND OPERATING PARAMETERS ............... 15

3.1 HOURS OF OPERATION .................. . . 15

3.2 NORMAL AND MAXIMUM PRODUCTION RATES . . . . . . . . . . 15

3.3 FUEL REQUIREMENTS . . . . . . . . . . . . . . . . . 15

3.4 RAW MATERIAL REQUIREMENTS . . . . . . . . . . . . . . . . . 17

3.5 EMISSIONS CONTROL SYSTEM . . . . . . . . . . . . . 17

4.0 EMISSIONS - TYPE AND QUANTITY .............. 19

4.1 REPRESENTATIVE EMISSIONS FROM THE EXISTING SOURCE ...... 19

4.2 PROJECTED ACTUAL CONTROLLED EMISSIONS . . . . . . . . . . . 19

4.3 PROJECTED POTENTIAL CONTROLLED EMISSIONS . . . . . . . . . . . 22

5.0 ANTICIPATED CONSTRUCTION SCHEDULE . . . . . . . . . . . . 23

6.0 A DEMONSTRATION OF BEST AVAILABLE CONTROL
TECHNOLOGY (BACT) SELECTION . . . . . . . . . . . . . . . 23

6.1 CONTROL EQUIPMENT AVAILABLE .............. 23

6.1 .1 Cover Gas................. . . 24

6.1.2 Tritium Generated Within the Reactor . . . . . . . . 25

6.1.3 Reactor/Pump Gallery/Test Assembly Cell Gas . . . . . . 28

6.2 CONTROL ALTERNATIVES . . . . . . . . . . . . . . . 28

6.2.1 Cover Gas . . . . . . . . . . . . . . . . . . . . . . . 28

6.2.2 Tritium Generated Within the Reactor . . . . . . . 30

6.2.3 Reactor/Pump Gallery/Test Assembly Cell Gas . . . . . . 31

6.3 BEST AVAILABLE RADIONUCLIDE CONTROL TECHNOLOGY . . . . . . . 32

6.3 .1 Cover Gas . . . . . . . . . . . . . . . . . . . . . . . 32

6.3.2 Tritium Generated Within the Reactor . . . . . . . . 33

6.3.3 Reactor/Pump Gallery/Test Assembly Cell Gas . . . . . . 37

7.0 ANALYSIS OF PRESENT AIR QUALITY AT

THE PROPOSED SOURCE LOCATION . . . . . . . . . . . . . 38

8.0 ANALYSIS OF THE PROPOSED SOURCE ON

AMBIENT AIR QUALITY . . . . . . . . . . . . . . . 39

8.1 MODEL DESCRIPTION . . . . . . . . . . . . . . . . . . 39

8.2 RESULTS OF MODELING ANALYSIS . . . . . . . . . . . . . . 40

9.0 DEMONSTRATE THAT PROPOSED EMISSIONS WILL NOT CAUSE A VIOLATION OF STATE OR NATIONAL AMBIENT AIR QUALITY STANDARDS . . . . . . . . . 41 


\section{CONTENTS (continued)}

10.0 DEMONSTRATE THAT PROPOSED EMISSIONS WILL NOT CAUSE AN EXCURSION OVER PSD INCREMENTS FOR PARTICULATE MATTER AND SULFUR DIOXIDE

11.0 DEMONSTRATE THAT PROPOSED EMISSIONS WILL NOT IMPAIR VISIBILITY IN A CLASS I AREA OR OTHER SENSITIVE AREAS . . . . . . . . . . . 41

12.0 DISCUSS THE PROPOSED PROJECT'S EFFECTS ON RESIDENTIAL OR COMMERCIAL GROWTH, VEHICULAR TRAFFIC, SOILS, VEGETATION, ACID DEPOSITION AND ANY OTHER AIR QUALITY RELATED VALUES . . . . . 41

13.0 REFERENCES . . . . . . . . . . . . . . . . . 42 APPENDIXES:

A. Literature SEARCH .................. . . . . . . .

B. DERIVED CONCENTRATION GUIDE ................... B- 


\section{LIST OF FIGURES}

1 Location of the Hanford Site ............... 2

2300 Area Details ................. 3

3 SP-100 Nuclear Test Assembly in Vacuum Vessel . . . . . . . . 6

4 SP-100 Ground Engineering System Nuclear Assembly Test . . . . . . . 7

5 Core Map for the Nuclear Assembly . . . . . . . . . . . . . . . 8

6 Flow Diagram for the Primary Heat Transport System . . . . . . . . 11

7 Flow Diagram for the Secondary Heat Transport System . . . . . . . . 13

8 Reactor, Pump Gallery and Test Assemply Cells . . . . . . . 16

\section{LIST OF TABLES}

1 Controlled Emission Rates Of Tritium, Argon, and Carbon . . . . . . 22

2 Cover Gas Control Alternatives ................ . 24

3 Tritium Control Alternatives . . . . . . . . . . . 26

4 Cell Gas Control Alternatives . . . . . . . . . . . . 28

5 Costs For Tritium Control Alternatives . . . . . . . . . . 36

6 Comparison of Tritium Controls ................ . . 37

7 Offsite Dose Estimates for an Individual Receiving Maximum Exposure to Airborne Radiological Emissions From SP-100 (mem/yr) . . . . . . . 40 
DOE/RL- $90-14$

This page intentionally left blank.

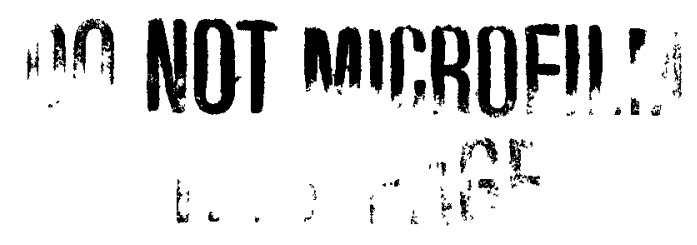


DOE/RL $-90-14$

\section{PREVENTION OF SIGNIFICANT DETERIORATION APPLICATION \\ FOR APPROVAL TO CONSTRUCT SP-100 GROUND \\ ENGINEERING SYSTEM TEST SITE}

\section{INTRODUCTION}

The following application is being submitted by the U.S. Department of Energy, Richland Operations Office, P.0. Box 550, Richland, Washington 99352, pursuant to WAC 173-403-080, and in compliance with the Department of Ecology "Guide to Processing A Prevention of Significant Deterioration (PSD) Permit" for a new source of airborne radionuclide emissions at the Hanford Site in Washington State (Figure 1). The new source, the SP-100 Ground Engineering System (GES) Test Site, will be located in the 309 Building of the 300 Area, as shown in Figure 2 .

The U.S. Department of Energy (DOE), the National Aeronautics and Space Administration (NASA), and the U.S. Department of Defense (DOD) have entered into an agreement to jointly develop space nuclear reactor power system technology. The DOE has primary responsibility for developing and ground testing the nuclear subsystem. A ground test of a reactor is necessary to demonstrate technology readiness of this major subsystem before proceeding with the flight system development and demonstration.

The SP-100 GES Test Site will provide a location for the operation and testing of a prototype space-based, liquid metal-cooled, fast flux nuclear reactor in an environment closely simulating the vacuum and temperature conditions of space operations. The purpose of the GES is to develop safe, compact, light-weight and durable space reactor power system technology. This technology will be used to provide electric power, in the range of tens to hundreds of kilowatts, for a variety of potential future civilian and military space missions requiring long-term, high-power level sources of energy.

As part of this program, it is proposed that the SP-100 test reactor be tested in the existing decommissioned Plutonium Recycle Test Reactor (PRTR) containment building ( 309 Building). The reactor will be operated for at least three months and up to $2 \mathrm{yr}$. Following the test, the 309 Building will be decontaminated for potential use in other programs.

It is projected that this new source of emissions will contribute approximately $0.05 \mathrm{mrem} / \mathrm{yr}$ dose (see Section 8.2 of the permit application) to the maximally exposed offsite individual. This projected dose is approximately $0.5 \%$ of the 40 CFR 61.92 regulatory 1 imit of 10 mrem (Section 9.0 of the permit application). This application is being submitted in response to those projected emissions that would provide the described offsite dose. 
Figure 1. Location of the Hanford Site.

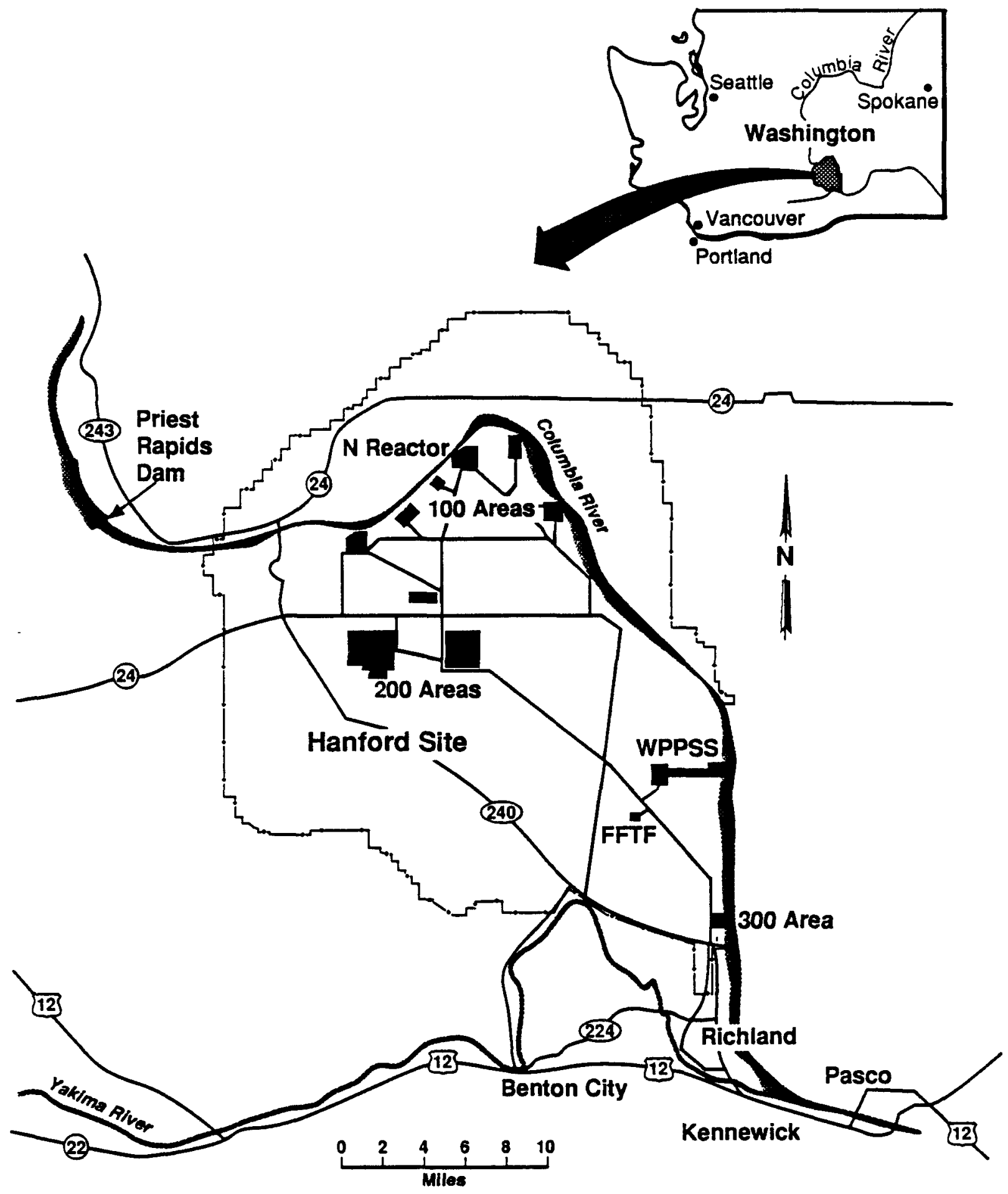

39002096.6 


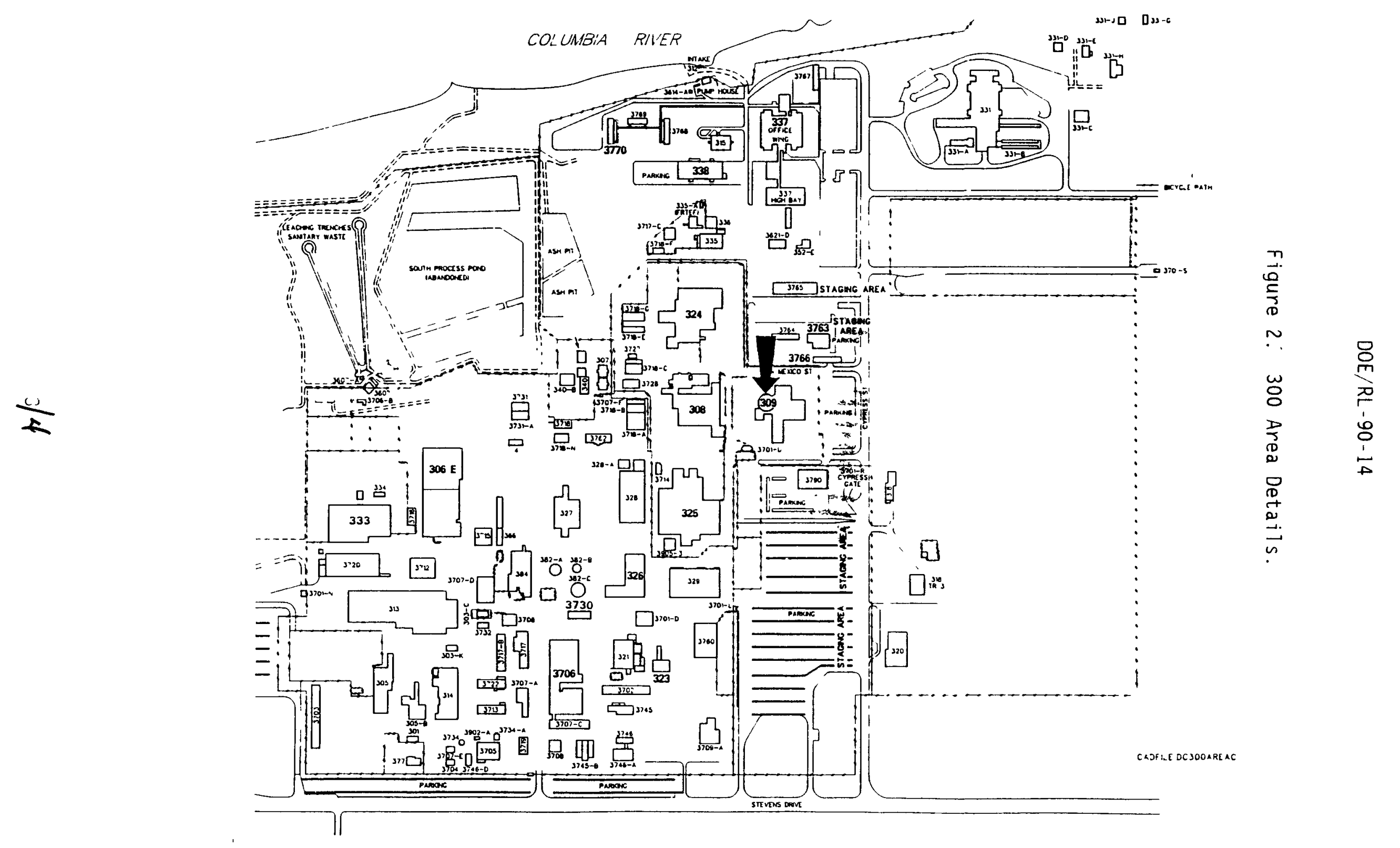


DOE/RL- $90-14$

This page intentionally left blank.

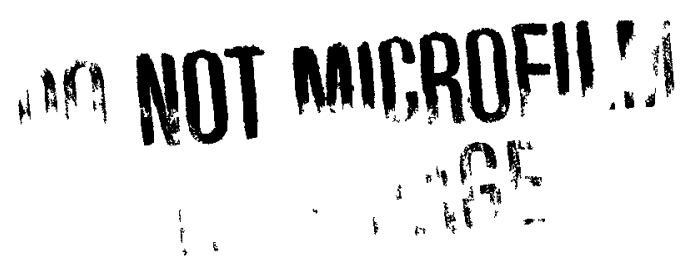




\section{PREVENTION OF SIGNIFICANT DETERIORATION APPLICATION \\ FOR APPROVAL TO CONSTRUCT SP-100 GROUND \\ ENGINEERING SYSTEM TEST SITE}

\subsection{PROJECT LOCATION}

The SP-100 Ground Engineering System (GES) Test Site will be located on the Hanford Site, within the 309 Building of the 300 Area, as shown in Figures 1 and 2 .

\subsection{PROCESS DESCRIPTION}

\section{Reactor Overview}

The SP-100 GES, as described in this section, will be as prototypic of the technology required for orbiting space subsystems as is practical. Figure 3 depicts the nuclear assembly. Figure 4 is a simplified diagram of the SP-100 nuclear test assembly and support systems.

The reactor is a fast-neutron-spectrum design with sealed uranium nitride (UN) fuel pins contained in a single vessel with liquid lithium circulated as the coolant. The reactor core is about $35 \mathrm{~cm}$ (13.6 in.) in diameter by $40 \mathrm{~cm}$ ( 15.5 in.) high. Niobium-1\%zirconium (Nb-12r) refractory metal is used for the reactor fuel cladding and structural material. The reactor is nominally rated at 2.4 MWt and delivers its thermal energy to liquid lithium at $1072{ }^{\circ} \mathrm{C}\left(1961^{\circ} \mathrm{F}\right)$. The core structure is a honeycomb array of 24 hexagonal ducts, each containing up to 37 fuel pins (Figure 5). One or two locations in each duct do not contain a fuel pin but are bayonet tubes connected to an auxiliary cooling system (ACS) for decay heat removal.

Seven of the ducts in the core honeycomb structure contain hexagonal thimbles with a cylindrical cavity. Six of the thimbles receive the in-core safety rod boron carbide absorber elements. The seventh, central thimble contains the neutron source and instrumentation to measure core temperatures. The reactor is controlled by 12 hinged, radial reflector elements of beryllium oxide located outside the reactor vessel. The safety rod and control reflector systems are independent. Each provides sufficient negative reactivity during reactor assembly and adequate control and shutdown during reactor operation. 
Figure 3. SP-100 Nuclear Test Assembly in Vacuum Vessel.

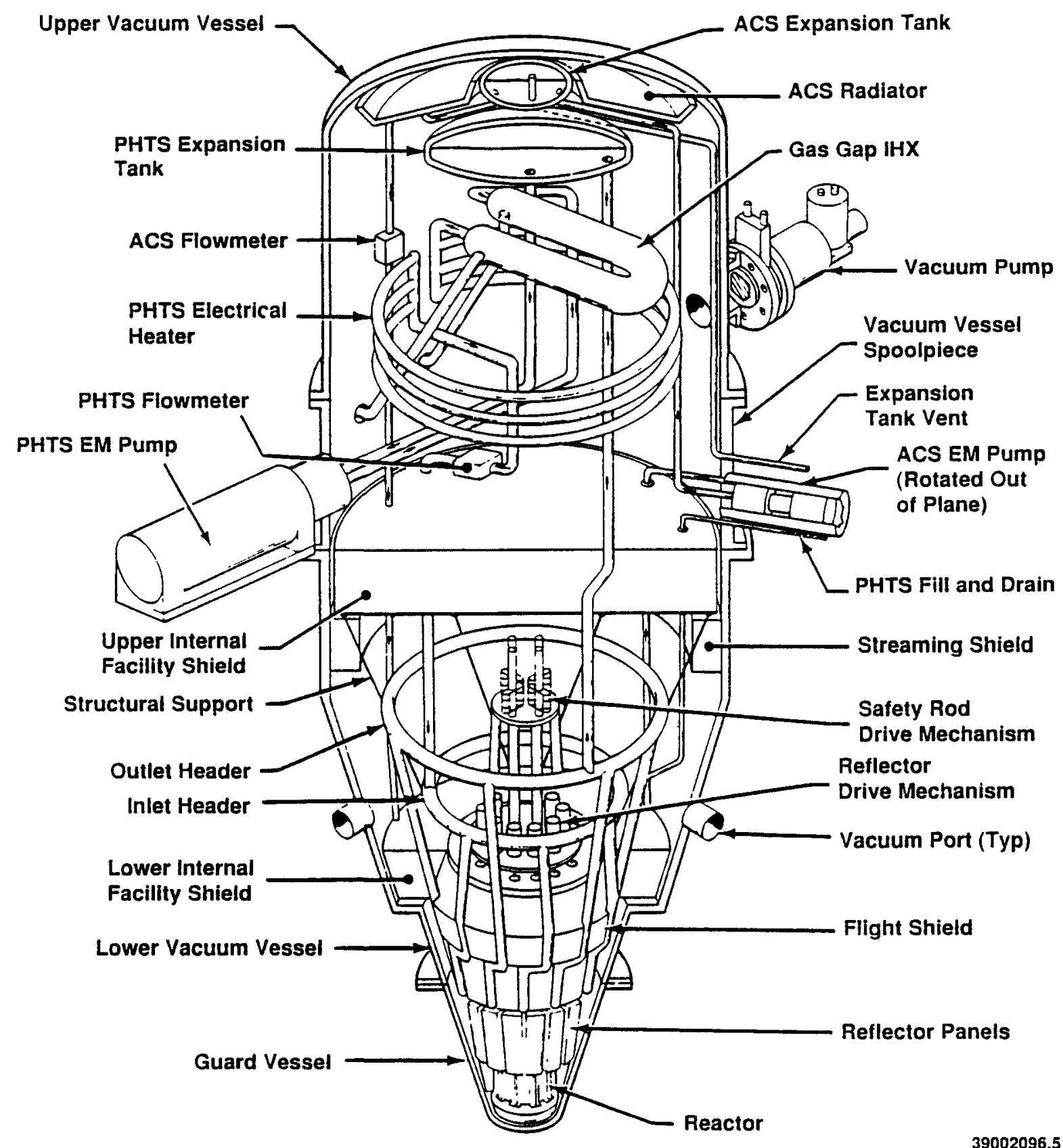




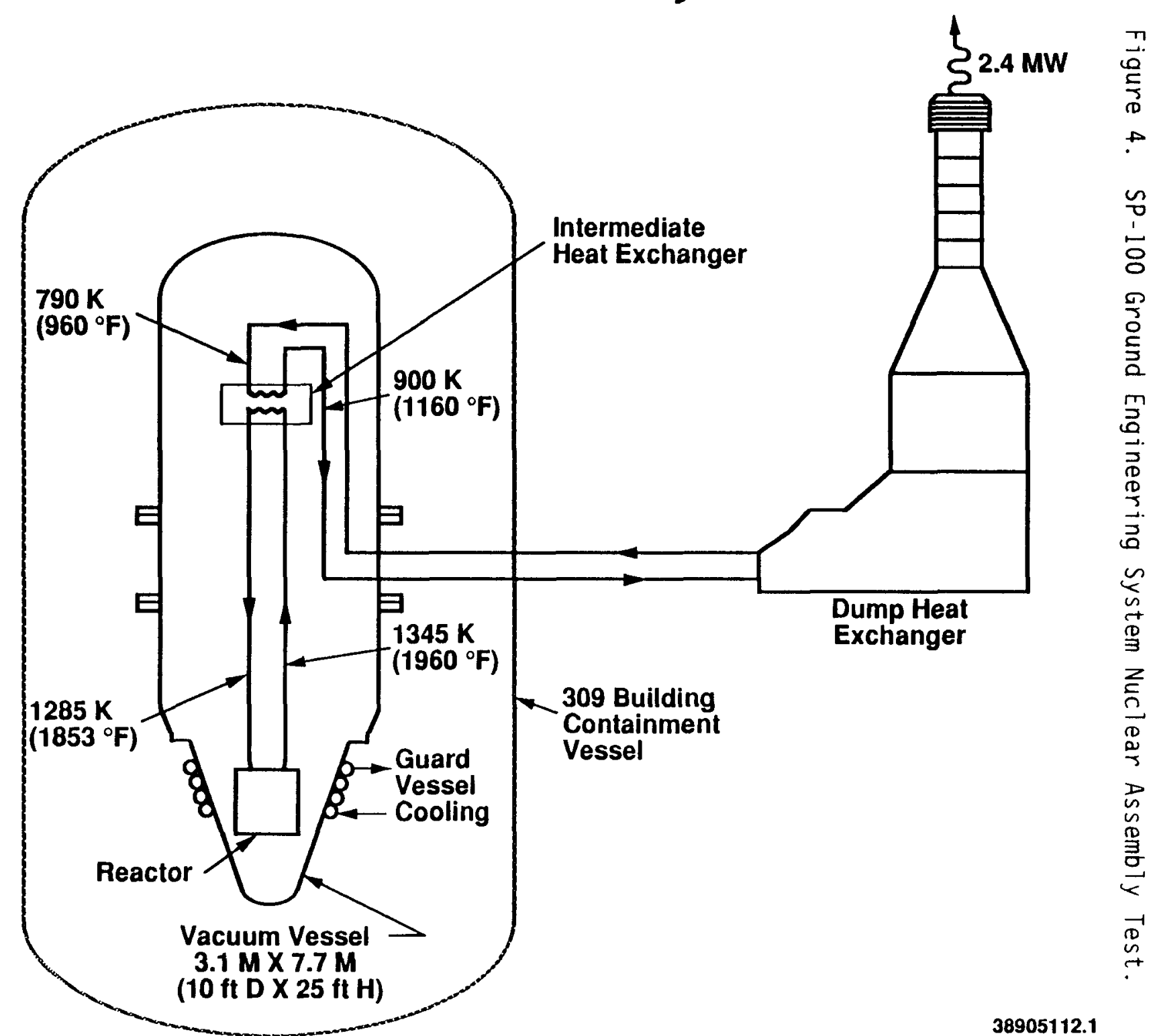




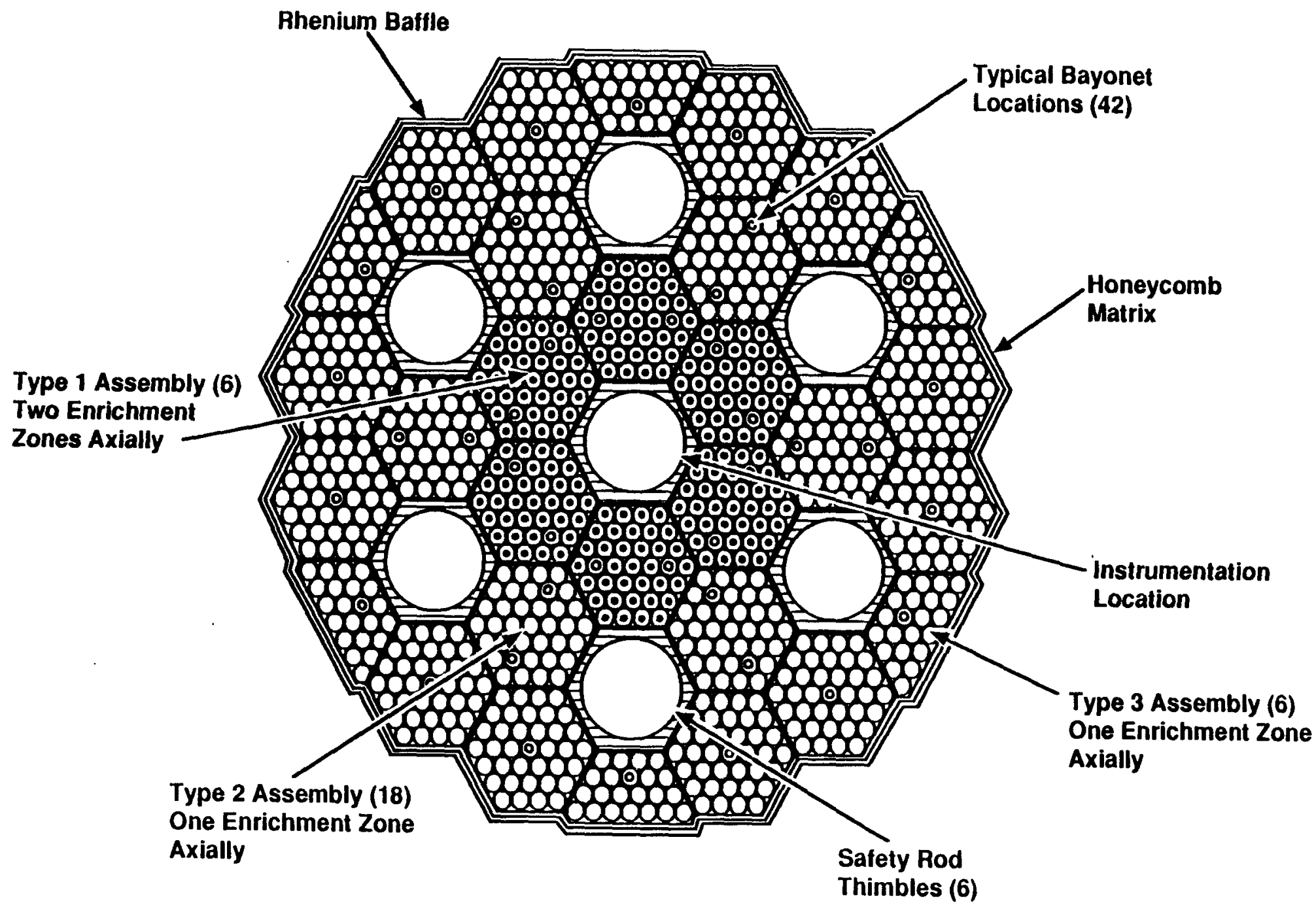


The SP-100 GES reactor, controls, and prototypic flight shield will be tested to demonstrate the integrated nuclear subsystem performance and interface compatibility. Reactor operation will occur within a vacuum vessel whose wall temperature will be $77^{\circ} \mathrm{C}\left(170^{\circ} \mathrm{F}\right)$ next to the flight shield and reactor vessel to approximate radiant heat losses from the reactor and shield encountered in space. The vacuum system will operate at about $10^{-5}$ torr to simulate a space environment and avoid oxidation of the refractory metal components of the primary heat transport system (PHTS).

\section{Vacuum Vesse1}

The SP-100 GES reactor, the flight shield, the lower and upper facility shields, and the PHTS will be housed in a vacuum vessel (Figure 3 ). The vacuum vessel will be a segmented right circular cylinder about $3.0 \mathrm{~m}$ (10 ft) in diameter with an overall length of $7.6 \mathrm{~m}(25 \mathrm{ft})$. The vacuum vessel will be fabricated from stainless steel in accordance with the American Society of Mechanical Engineers (ASME) Boiler and Pressure Vessel Code. The vacuum vessel will be supported with an interfacing structure to the containment building test cell concrete structures. The vessel will form a vacuum boundary that will allow evacuation to a high vacuum level. This vacuum level not only simulates space environment but also precludes the reaction of atmospheric and other gases with the refractory materials of the test assembly. The vacuum vessel will also be temperature controlled to provide a heat sink for radiative heat rejection from the test assembly.

\section{Vacuum System}

The SP-100 GES Vacuum System will achieve the high vacuum level inside the vacuum vessel by a two-stage pumping system. The rough vacuum pumping package consists of mechanical pumps, which will reduce system pressure from one atmosphere (760 torr) down to $10^{-1}$ torr. The roughing package also contains cryostats to prevent oil back-streaming from the pumps to the vacuum vessel. The roughing package can be isolated from the vacuum vessel by separate isolation valves. The next pumping stage, rough to high vacuum, is achieved by a combination of turbomolecular and cryopumps. The cryopumps provide the turbopumps with additional pumping capacity. This pumping package will reduce the vacuum vessel pressure from $10^{-1}$ torr to $10^{-5}$ torr. The turbomolecular and cryopumps are connected to the vacuum vessel and are individually isolated by vacuum valves.

\section{Containment Structure}

The existing containment vessel is an all steel, cylindrical vessel $24.4 \mathrm{~m}(80 \mathrm{ft})$ in diameter and $36.9 \mathrm{~m}$ (121 ft) high, extending $22.9 \mathrm{~m}(75 \mathrm{ft})$ above grade. The containment vessel was designed, constructed, and tested in conformance with the ASME Boiler and Pressure Vessel Code, Section VIII, Division 1. The bottom of the vessel is $14 \mathrm{~m}(46 \mathrm{ft})$ below grade and is supported on a reinforced concrete pad. The internal design pressure of the vessel is $15 \mathrm{lb} / \mathrm{in}^{2}$ (gage), and the design maximum external pressure is $0.501 \mathrm{~b} / \mathrm{in}^{2}$ (gage). 
The containment vessel above the main operating floor is protected from internal missiles by a $0.3-\mathrm{m}-(1-\mathrm{ft})$ thick concrete cylindrical wall that extends approximately $10 \mathrm{~m}(33 \mathrm{ft})$ above grade. This structure also supports the rails for the overhead crane.

A 5,000 $\mathrm{ft}^{3} / \mathrm{min}$ supply unit, complete with heating coils and filters, provides general heating and ventilation to the containment area. The heating and ventilation exhaust fan is housed in the exhaust fan pit which exhausts to the $30.5-\mathrm{m}(100-\mathrm{ft})$ stack east of the fan pit. Two stages of highefficiency particulate air (HEPA) filters are available prior to exhausting. Since no routine releases of radioactive particles are anticipated, the HEPA filters are provided as a precaution should an unplanned event occur that could result in the generation of radioactive particles. In addition, containment isolation valves are provided in the heating, ventilation and air conditioning (HVAC) system to limit radioactive releases in the unlikely event of an accident.

\section{Primary Heat Transport System}

The PHTS (Figure 6) transfers the thermal energy generated in the reactor to the secondary heat transport system (SHTS). The PHTS consists of a single lithium loop that connects to the outlet plenum of the reactor. The lithium flows through multiple heat transport pipes to a ring header, to an expansion tank, through an electromagnetic (EM) pump, through the tube side of an intermediate heat exchanger (IHX), to an electrical heater, and finally to the inlet piping of the reactor.

The expansion tank is basically a tank with the inlet and outlet pipes connected to the bottom of it. As the lithium heats and cools, it expands and contracts. The vapor space in the expansion tank contains a gas which contracts as the lithium expands and expands as the lithium contracts. This gas, which is called the cover gas, is provided to enable the lithium to expand and contract without causing large swings in the pressure of the system.

The electric heater is used to provide heat input for hot functional testing and isothermal physics testing without reactor heating.

The PHTS loop is located completely inside the vacuum vessel, though the EM pump stator is located external to the vacuum vessel. The EM pump stator is in a thimble that forms an extension of the vacuum vessel. The thimble maintains a vacuum environment for the pump duct.

The nominal reactor inlet temperature is $1016{ }^{\circ} \mathrm{C}\left(1861{ }^{\circ} \mathrm{F}\right)$ with a nominal outlet temperature of $1072^{\circ} \mathrm{C}\left(1961^{\circ} \mathrm{F}\right)$. 


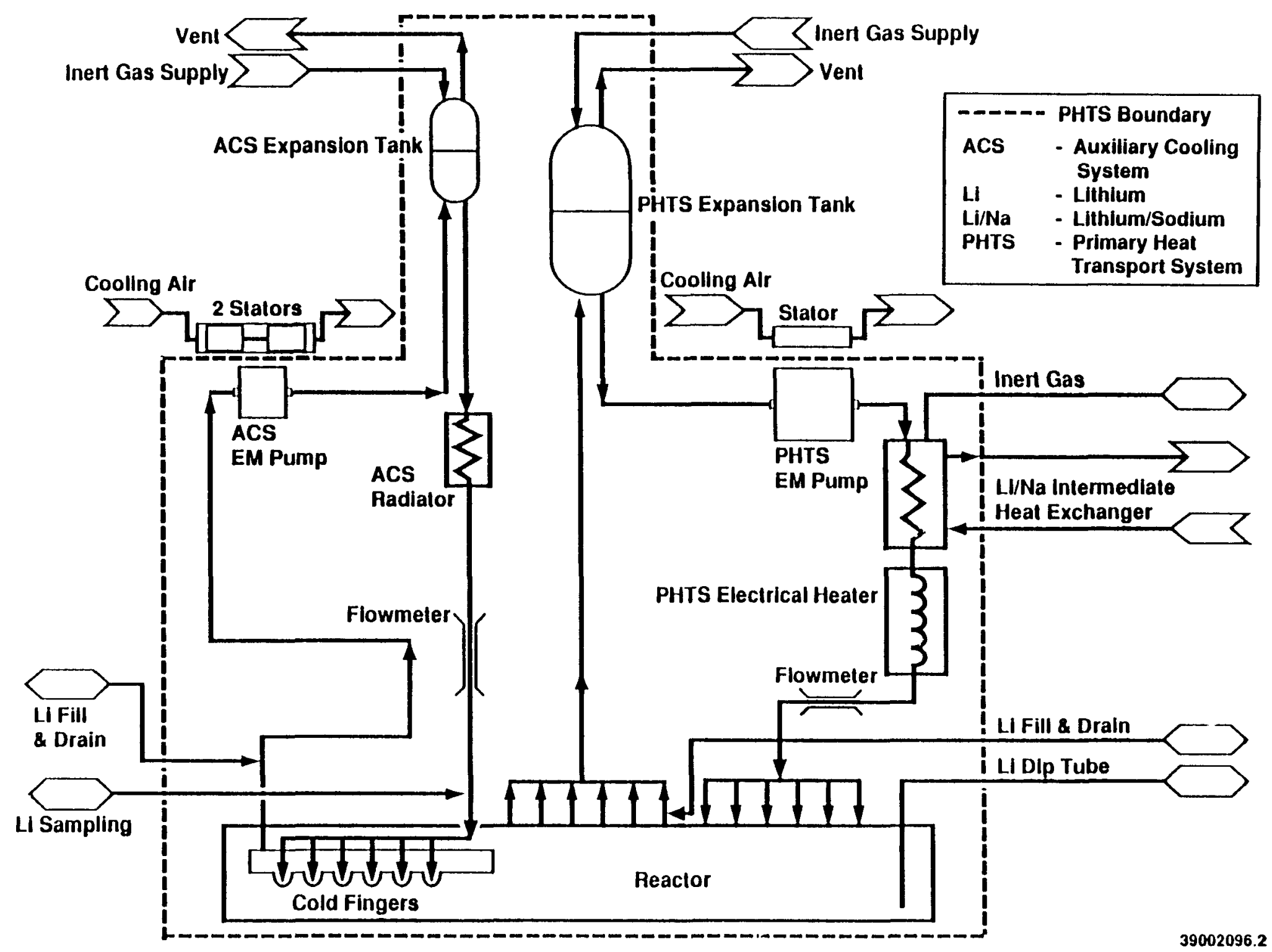




\section{Secondary Heat Transport System}

The SHTS (Figure 7) provides for the operational rejection of the reactor heat to ambient air using sodium as the heat transfer coolant. The reactor heat is transferred from the PHTS into the stainless steel SHTS through the IHX located inside the vacuum vessel. Heat is rejected to the atmosphere by a sodium-to-air dump heat exchanger (DHX).

The SHTS loop consists of the shell side of the IHX, two EM pumps, a flow meter, miscellaneous valves and connecting pipes, and a forced-air DHX. Expansion and contraction of the sodium over the operating temperature range is accommodated by an expansion tank with an argon cover gas system. This expansion tank is similar in design to that used in the PHTS and is located outside the vacuum vessel in the DHX structure.

\section{Auxiliary Cooling System}

The ACS provides an independent, redundant decay heat removal path for the test reactor in the unlikely event of an off-normal occurrence that seriously impairs the ability of the PHTS to transfer reactor heat to the ultimate heat sink (e.g., failure of the PHTS boundary, failure of the SHTS boundary, or failure of the $\mathrm{DHX})$. The core incorporates 42 bayonetconfigured, heat-absorbing tubes interspersed among the fuel pins. These in-core bayonet tubes are connected to an auxiliary coolant loop with lithium as the cooling medium. The auxiliary cooling loop transports decay heat by forced circulation to a radiator panel inside the vacuum vessel. The profile of the ACS components also promotes natural convective flow in the loop. The panel radiates decay heat to the cooled vacuum vessel wall.

The secondary ACS (SACS), located outside the vacuum vessel, transports the decay heat from the vacuum vessel wall to the ultimate heat sink. The path is independent of the main coolant loop and capable of abundant cooling.

\section{Vacuum Vessel Cooling Systems}

The vacuum vessel has three sections that require demineralized water cooling to simulate typical heat losses in a space environment and to fulfill their safety-related functions. The guard vessel section is cooled by the guard vessel cooling system (GVCS). The guard vessel requires cooling to remove sensible heat should the guard vessel be retaining lithium from a PHTS leak below the flight shield and radiative heat under normal conditions. The GVCS will also serve a conditional residual heat removal function if it is retaining the primary lithium leak and keeping the core submerged in lithium. The middle section of the vacuum vessel requires cooling to remove radiant heat from the PHTS and the flight shield and to maintain the required test environment. The top hemisphere of the vacuum vessel requires cooling to remove heat from the ACS radiator panel. The SACS will transfer the heat from the top of the vacuum vessel to a heat exchanger in containment. 


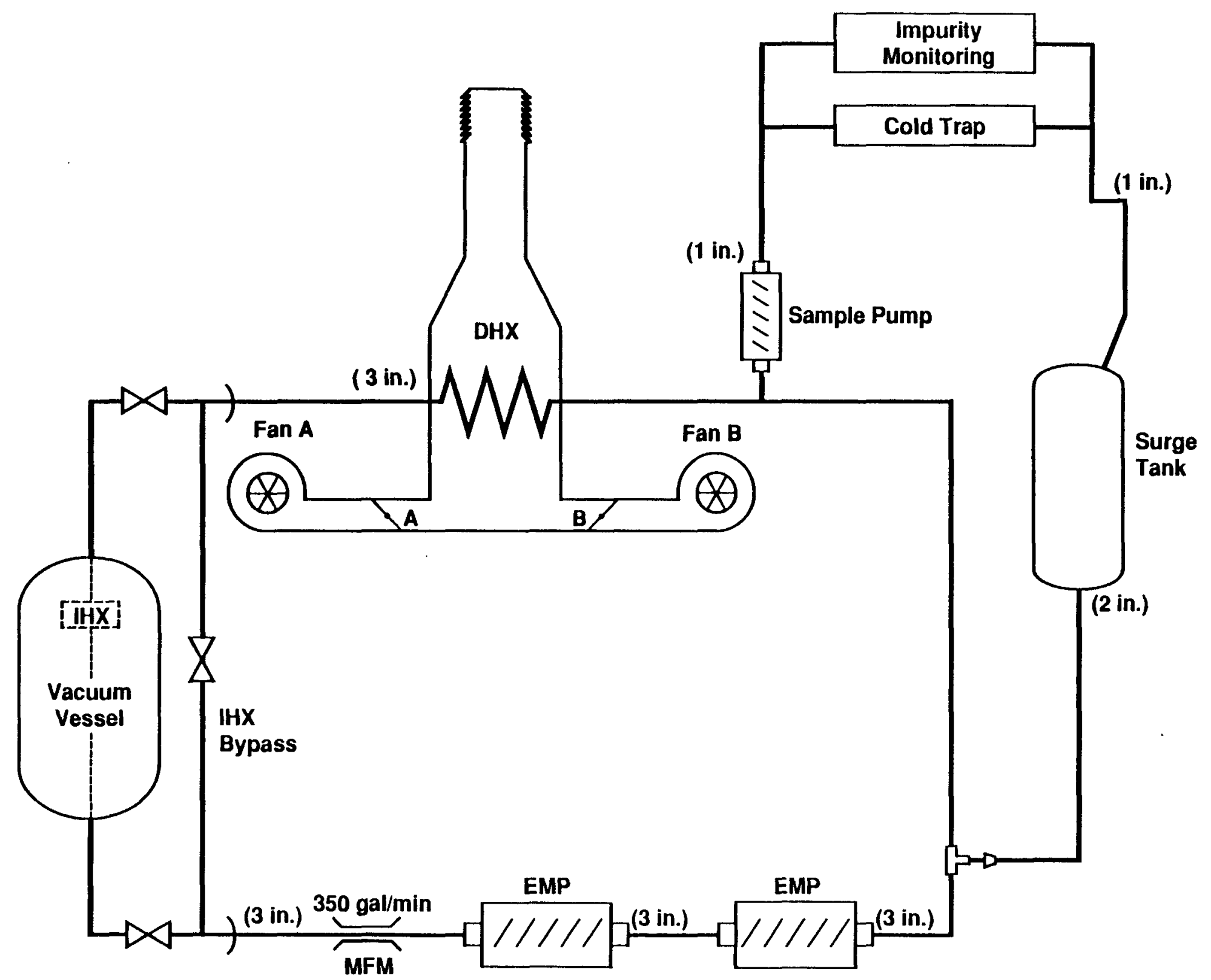

$\stackrel{?}{\stackrel{0}{0}}$

7
0
0
0
0
0
0 


\subsection{SOURCES OF EMISSIONS}

Three potential sources of radioactive gaseous emissions have been identified: (1) activated reactor cover gas; (2) tritium generated by neutron reaction with the lithium in the PHTS; (3) the activated reactor/pump gallery/test assembly cell gas generated by neutron reaction with gas surrounding the lower vacuum vessel. (Fission gases will also be generated; however, they will be generated and retained within the fuel pin cladding. Routine releases, then, of fission gases, except tritium, are prectuded by design and therefore, are, not considered in this analysis.)

\section{Activated Reactor Cover Gas}

The expansion tanks for the PHTS and the ACS are located within the vacuum vesse1. Therefore, the cover gas within these tanks will receive low amounts of exposure and can be activated depending on the cover gas utilized However, the SP-100 GES reactor PHTS and ACS are designed to operate aS sealed systems and will be opened only for sampling and at the end of the test period. Thus, there is no feed/bleed of reactor PHTS and ACS cover gas during operation. At the end of the test period, the reactor will be kept inactive for six months before disassembly. At the end of this six-month radioactivity decay period, the cover gas will be sampled. If the sample indicates that cover gas radioactivity exceeds release 1 imits, the gas will be pumped into a shielded tank for additional decay time. When the sample indicates that the cover gas activity is within release 1 imits, it will be discharged through the monitored containment exhaust plenum. Thus, no routine emissions from the reactor cover gas are expected.

\section{Tritium $\left({ }^{3} \mathbf{H}\right)$ Within the PHTS}

Tritium will be produced as the result of neutron bombardment of the lithium-6 $\left({ }^{6} \mathrm{Li}\right)$ in the lithium coolant. This tritium will pass through the walls of the pipes in the PHTS and ACS and will be pumped by a turbomolecular pump, monitored, and discharged up the stack. Tritium will also be generated within the reflector panels and the safety rods of the reactor. This tritium will pass from these components into the vacuum vessel and will also be pumped by a turbomolecular pump, monitored, and discharged up the stack.

Another source of tritium release will result from cleaning the core following reactor operation. Nitrogen is used to convert lithium in the PHTS and ACS into 1ithium nitride. After the nitrating process, the residue, which is in the form of solid lithium nitride will then be removed with a water/acid flush of the coolant system. Any tritium which is dissolved in the lithium will not react with the nitrogen and will therefore be discharged up the stack, within release limits. 


\section{Reactor/Pump Gallery/Test Assembly Cell Gas}

The reactor cell is located between this interfacing structure, the bottom half of the vacuum vessel, and the floor of the containment building (see Figure 8). The test assembly cell is located above and around the upper portion of the vacuum vessel. Between the test assembly cell and the reactor cell and around the vacuum vessel is the pump gallery cell. Some of the neutrons produced when the reactor is operating pass through the vacuum vessel and into the reactor cell, the pump gallery cell, and the test assembly cel1. Gaseous activation products may be formed when the neutrons interact with the cell gas. The activation products formed depend on the type of gas utilized as the cell gas. This gas is held in the reactor cel1, the pump gallery cell, and the test assembly cell. Any release from these cells is from seal leakage and is to containment. The leakage is carried, in turn, by ducting to the stack, monitored, and exhausted to the atmosphere.

\subsection{DESIGN AND OPERATING PARAMETERS}

\subsection{HOURS OF OPERATION}

It is projected that up to 2 yr may be required to validate the performance of the SP-100 GES nuclear assembly. During this test period, the SP-100 GES reactor will undergo testing while "down" (no fuel being irradiated) and while being operated at various power levels for varying lengths of time. Under current scheduling, the longest uninterrupted period of time the reactor will be operated at full power is 60 days. During this 60 -day test period the reactor will be in operation $24 \mathrm{~h} /$ day. Total full power level operations are projected to require approximately three months during the 2-yr period.

\subsection{NORMAL AND MAXIMUM PRODUCTION RATES}

As previously described, the proposed project constitutes a test and will not produce a product other than information. However, while the reactor is being operated, heat will be generated and that heat will be discharged to the atmosphere. At full power the reactor will discharge approximately 2.4 MWt to the atmosphere.

\subsection{FUEL REQUIREMENTS}

Fuel requirements for the SP-100 GES test have been divided into two categories: (1) nuclear fuel for the reactor: (2) electrical requirements to provide necessary power to the test site. 


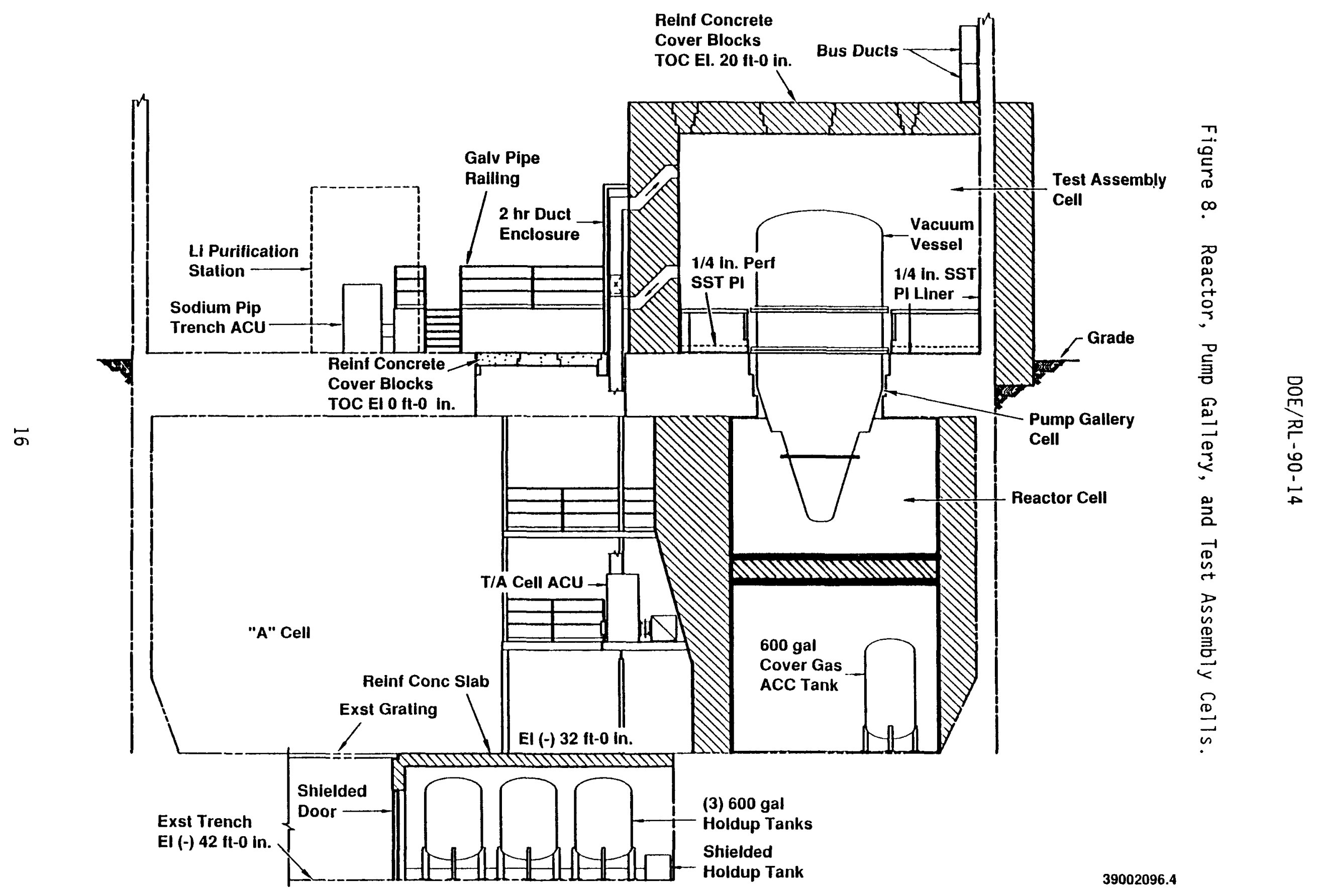


The total nuclear fuel requirement for the $2 \mathrm{yr}$ test has been determined to be approximately $154 \mathrm{~kg}$ of uranium-235 (235 U).

The electrical load has been estimated at $2.5 \mathrm{MW}$ to $5 \mathrm{MW}$.

\subsection{RAW MATERIAL REQUIREMENTS}

Raw material requirements for the SP-100 GES test have been estimated as follows:

- Lithium-7 ( $\left.{ }^{7} \mathrm{Li}\right): \quad 175 \mathrm{ga}$

- Liquid sodium: $\quad 700$ gal

- Argon: $262,500 \mathrm{ft}^{3} /$ month

- Water (cooling): $\quad 6,000$ to 10,000 gal (closed loop)

- Breathing air: $\quad 30$ bottles at $311 \mathrm{stdft}^{3} /$ bottle

- Nitrogen: 6 bottles at $301 \mathrm{stdft}^{3} /$ bottle

- Helium: 2 bottles at $286 \mathrm{stdft}^{3} /$ bottle.

\subsection{EMISSIONS CONTROL SYSTEM}

As described in Section 2.1, two sources of routine radioactive airborne emissions have been identified:

- Tritium generated by neutron reaction with the lithium in the PHTS

- Activated reactor/pump gallery/test assembly cell gas generated by neutron reaction with gas surrounding the vacuum vessel.

The following describes the systems being developed to control these two sources of emissions.

\section{Tritium Within the PHTS}

Releases of tritium from the reactor will be controlled by the use of lithium enriched in ${ }^{7} \mathrm{Li}$. Naturally occurring 1 ithium is comprised of two isotopes $\left(7.5 \%{ }^{6} \mathrm{Li}\right.$ and $\left.92.5 \%{ }^{7} \mathrm{Li}\right)$. The isotope ${ }^{6} \mathrm{Li}$ absorbs a neutron and decays to yield nonradioactive helium and radioactive tritium gases. The isotope ${ }^{7} \mathrm{Li}$ will provide two nonradioactive helium atoms as a result of neutron absorption. Therefore, lithium enriched with ${ }^{7} \mathrm{Li}$ (to $99.9 \%$ with 1 ess than $\left.0.1 \%{ }^{6} \mathrm{Li}\right)$ has been selected as the coolant and the tritium control mechanism. Lithium of this enrichment reduces radioactive tritium production by a factor of 75 . 


\section{Reactor/Pump Gallery/Test Assembly Cell Gas}

The SP-100 GES utilizes a sealed-cell gas system to control radioactive emissions. By utilizing a sealed-cell gas system, the cell gas can be held for a relatively long period of time to allow the activation products to decay to stable atoms once the reactor is shut down and the neutron source that causes activation is eliminated. This will provide a hold-up time much greater than can be provided by either reducing the flowrate of the exhaust gas while the reactor is operating or by increasing the volume of exhaust ducting (see discussion in Section 6.1.1). It should be noted, however, that the use of a sealed system will not totally eliminate radioactive emissions from the cell gas system while the reactor is operating.

Radioactive emissions are the result of leakage from the three cells into the containment area around the cells resulting from numerous penetrations (openings for pipes, instrumentation, access) into the cells. (The cover gas system is not expected to leak because it is a completely isolated system.) Special precautions will be taken and design features will be developed to 1 imit the leak rate to less than $310 \mathrm{~cm}^{3} / \mathrm{s}$ from the pump gallery and the test assembly cells. These precautions include the following actions.

- The test assembly cell and the pump gallery cell will be provided with a high-integrity liner (welded steel-lined construction), a high-integrity seal design, and welded penetrations.

- The reactor cell will be provided with a high-integrity liner (welded steel-lined construction), welded flexible seal, and highintegrity penetrations.

The leakage rate from the reactor cell is not critical because of the slow activation rate of the nitrogen cell gas. In the event that leakage occurs, the net mass flowrate will be out of the cells and into the containment building because the cells will be maintained at a positive pressure. (The inerting gas is supplied to the cell as required to maintain this positive pressure.) The cells are maintained at a positive pressure to ensure that the oxygen concentration in the cells is below limits specified to protect the reactor structural material (Nb-1Zr alloy) in the event of a leak into the vacuum vessel. At high temperatures, the $\mathrm{Nb}-1 \mathrm{Zr}$ alloy rapidly reacts with oxygen causing damage to the reactor. However, if inleakage of oxygen were to occur, a backup feed-and-bleed system has been provided to limit the oxygen concentration in the cells. If the cell oxygen concentration approaches the specified limits, the inert gas will be pumped from the cell or cells at a total rate of $5 \mathrm{ft} / \mathrm{min}$. The inert gas flows through a holdup tank and is exhausted out the stack. The holdup tank will ensure that any radioactive components have decayed to an acceptable level. A radiation monitor at the inlet to the stack will ensure release limits are not exceeded. 


\subsection{EMISSIONS - TYPE AND QUANTITY}

\subsection{REPRESENTATIVE EMISSIONS FROM THE EXISTING SOURCE}

The 309 Building facility was first occupied in 1960. It was originally designed and built as a high-pressure containment facility for the pressurized, water-cooled 70-MWt Plutonium Recycle Test reactor (PRTR). The PRTR mission was the development of technology for the use of plutonium in power reactors. The reactor was shut down in 1969. A11 PRTR fuel was removed. The containment vessel aboveground level was made into a clean room shop, and the below-grade areas were monitored and maintained to support clean room conditions. Since decommissioning of the PRTR, the facility has undergone many modifications for new uses. It has most recently been used for computer systems maintenance and repairs and for glovebox fabrication and modification.

Since decommissioning, the only "emissions" from the 309 Building stack have been from the HVAC system functioning to heat or cool the facility. These emissions are free of any radioactive or other contaminants. The average temperature at the stack is $25.6{ }^{\circ} \mathrm{C}\left(78^{\circ} \mathrm{F}\right)$. The average stack flow rate is $5,000 \mathrm{ft}^{3} / \mathrm{min}$.

\subsection{PROJECTED ACTUAL CONTROLLED EMISSIONS}

The emissions of gaseous radionuclides from the SP-100 facility are anticipated to be activation products formed as described in Section 2.1. Those activation products will be argon-41 $\left({ }^{41} \mathrm{Ar}\right)$, carbon-14 $\left({ }^{14} \mathrm{C}\right)$, and ${ }^{3} \mathrm{H}$. No particulate emissions are expected.

NOTE: Though 365 days of operation is used in the following calculations, the reactor is not expected to operate continuously for a year (Section 3.1).

Tritium $\left({ }^{3} \mathrm{H}\right)$ :

The emission rate for gaseous tritium was set equal to estimates of the total amount of tritium to be produced within the reactor system. The total amount of tritium estimated to be produced during 1 yr of reactor operation is $522 \mathrm{Ci}$ which is within release guidelines. That tritium production rate was estimated as follows:

- The quantity (grams) of tritium produced by the neutron activation of the lithium coolant was calculated using the ORIGEN II Code (Croff 1985) for a range of full power operations between one day and $2 \mathrm{yr}$. It is projected that one ful1-power day will produce $1.52 \times 10^{-4} \mathrm{~g}^{3} \mathrm{H} / \mathrm{d}$. 
- Grams of tritium produced were then converted to curies using the following formula:

$$
\operatorname{SpA}=\lambda N=(\ln 2) N / T_{1 / 2}
$$

where:

$$
\begin{aligned}
\mathrm{SpA}= & \text { Specific Activity }=\text { (disintegrations per unit time) } / \text { (unit mass) } \\
\mathrm{T}_{1 / 2}= & \text { Half-life of specific radionuclide }=12.6 \mathrm{yr} \text { for tritium } \\
\lambda= & \text { Decay constant for the specific radionuclide }=1 \mathrm{n} 2 / \mathrm{t}_{1 / 2} \\
= & 0.69315 / 12.6 \mathrm{yr} \\
N= & \text { Number of radioactive atoms per unit mass }=\text { Avogadro's number } / \\
& \text { atomic mass of specific radionuclide }=6.0225 \times 10^{23} / 3.01605 .
\end{aligned}
$$

yielding

$$
9413.5 \mathrm{Ci} / \mathrm{g} \text { of }{ }^{3} \mathrm{H}
$$

Converting curies of ${ }^{3} \mathrm{H} / \mathrm{g}$ of ${ }^{3} \mathrm{H}$ to curies of ${ }^{3} \mathrm{H} / \mathrm{d}$ :

$$
\left(9413.5 \mathrm{Ci} / \mathrm{g}^{3} \mathrm{H}\right)\left(1.52 \times 10^{-4} \mathrm{~g}^{3} \mathrm{H} / \mathrm{d}\right)=1.4 \mathrm{Ci}{ }^{3} \mathrm{H} / \mathrm{d}
$$

Converting curies of ${ }^{3} \mathrm{H} / \mathrm{d}$ to curies of ${ }^{3} \mathrm{H} / \mathrm{yr}$ :

$$
\left(1.4 \mathrm{Ci}{ }^{3} \mathrm{H} / \mathrm{d}\right)(365 \mathrm{~d})=522 \mathrm{Ci} / \mathrm{yr}=\text { Source Term. }
$$

\section{Argon-41:}

The emission rate of gaseous argon will be kept at or below the Derived Concentration Guide (DCG) of $1.0 \times 10^{-8} \mathrm{uCi} / \mathrm{mL}$ of air. (See Appendix $B$ for a discussion of the DCG.) This precipitates the release of approximately $0.75 \mathrm{Ci} / \mathrm{yr}$, as shown below:

- Release to be kept at DCG of $1.0 \times 10^{-8} \mathrm{uCi} / \mathrm{mL}$

- Stack flow rate $=5,000 \mathrm{ft}^{3} / \mathrm{min}$

- $1 \mathrm{~L}=0.0353 \mathrm{ft}^{3}$

$5,000 \mathrm{ft}^{3} / \min =1.42 \times 10^{5} \mathrm{~L} / \mathrm{min}=1.42 \times 10^{8} \mathrm{~mL} / \mathrm{min}$ 
- $\left(1.0 \times 10^{-8} \mathrm{uCi} / \mathrm{mL}\right)\left(1.42 \times 10^{8} \mathrm{~mL} / \mathrm{min}\right)(1,440 \mathrm{~min} / \mathrm{d})$

$=2.0 \times 10^{3} \mathrm{uCi} / \mathrm{d}$

- $\left(2.0 \times 10^{3} \mathrm{uCi} / \mathrm{d}\right)(365)=7.5 \times 10^{5} \mathrm{uCi} / \mathrm{yr}$

$=7.5 \times 10^{-1} \mathrm{Ci} / \mathrm{yr}=$ Source Term.

\section{Carbon-14:}

The reactor test cell will be a nitrogen-filled gas space surrounding the reactor core and the lower portion of the vacuum and guard vessel. Neutrons that escape the core and reflectors will interact with the nitrogen gas in the reactor cell through a neutron/proton reaction $(n, p)$, producing ${ }^{14} \mathrm{C}$.

The annual ${ }^{14} \mathrm{C}$ production rate of $1.7 \mathrm{Ci}$ was calculated based on the following assumptions:

- Free volume of $1,000 \mathrm{ft}^{3}$ in the reactor assembly cavity

- No additional shielding surrounding the guard vessel or in the cell.

The average neutron $f$ lux $(\phi)$ for the ${ }^{14} \mathrm{~N}(n, p){ }^{14} \mathrm{C}$ reaction in the reactor vault with no near-reactor shield was determined using the modeling code MCNP (Briesmeister 1986) and found to be $9.28 \times 10^{10}\left(n-b / \mathrm{cm}^{2}-\mathrm{s}\right)$. The atom density for nitrogen at standard temperature and pressure is $5.38 \times 10^{-5}$ (atoms $/ \mathrm{b}-\mathrm{cm})$. This gives a $\phi \sigma \mathrm{N}_{0}$ of $4.99 \times 10^{6}\left(\right.$ atoms $\left./ \mathrm{cm}^{3}-\mathrm{s}\right)$. The activation level of the gas leaking out of the reactor cell is given by:

$$
\frac{A=\left(\phi \sigma N_{0}\right) \lambda\left(1-e^{-}(\lambda+F / V)_{t}\right)}{(\lambda+F / V)}
$$

where:

$$
\begin{array}{rlrl}
A= & \text { Activation level of gas } & & \left(\mathrm{uCi} / \mathrm{cm}^{3}\right) \text { (NOTE: requires } \\
& \text { flowing out of reactor cell } & & \begin{array}{l}
\text { conversion from } \left.\left[\mathrm{dis} / \mathrm{s}-\mathrm{cm}^{3}\right]\right) \\
\left(\mathrm{n} / \mathrm{cm}^{2}-\mathrm{s}\right)
\end{array} \\
\phi= & \text { Neutron flux in cell } & & (\mathrm{b}) \\
\sigma= & \text { Cross section } & \\
& { }^{4} \mathrm{~N}(\mathrm{n}, \mathrm{p}){ }^{14} \mathrm{C} \text { in this case } & \\
\mathrm{N}_{0}= & \text { Atom density of target atoms } & \text { (atoms } / \mathrm{b}-\mathrm{cm}) \\
& \text { in the reactor ce11 } & \\
\lambda= & \text { Decay constant, } & \left(\mathrm{s}^{-1}\right) \\
& \text { for }{ }^{14} \mathrm{C} \text { in this case } & & \\
\mathrm{F}= & \text { Leak rate from reactor cell } & \left(\mathrm{cm}^{3} / \mathrm{s}\right)
\end{array}
$$




$$
\begin{aligned}
V= & \text { Reactor cell volume } \\
t= & \text { Time since start of reactor } \\
& \text { operation. }
\end{aligned}
$$

Constant values used were:

$$
\begin{aligned}
\mathrm{b} & =\text { Barn }=1.0 \times 10^{-24} \mathrm{~cm}^{2} \\
\phi \sigma & =9.28 \times 10^{10}\left([\mathrm{n}-\mathrm{b}] /\left[\mathrm{cm}^{c}-\mathrm{s}\right]\right) \\
\mathrm{N}_{0} & \left.=5.38 \times 10^{-5}([\text { atoms }] / \mathrm{b}-\mathrm{cm}]\right) \\
\lambda & =3.84 \times 10^{-12} \mathrm{~s} 1 \\
V & =1.005 \times 10^{8} \mathrm{~cm}^{3} \\
t & =6.30 \times 10^{7} \mathrm{~s} .
\end{aligned}
$$

Since the half-life of ${ }^{4} \mathrm{C}$ is very long relative to the leakage-tovolume ratio $(F / V)$, the total production over the 2 -yr reactor operating period is an accurate measure of potential ${ }^{+} \mathrm{C}$ emissions. The calculated total production is approximately $3.3 \mathrm{Ci}$ over $2 \mathrm{yr}$.

Assuming a uniform annual release of $1.7 \mathrm{Ci}$ of ${ }^{14} \mathrm{C}$, the stack release concentration would be $2.0 \times 10^{-y} \mathrm{uCi} / \mathrm{mT}$, which is well below the $D C G$ (Appendix B) of $5.0 \times 10^{-7} \mathrm{uCi} / \mathrm{ml}$.

Table 1 presents the controlled emission rates for ${ }^{41} \mathrm{Ar}, \mathrm{H}$, and ${ }^{14} \mathrm{C}$.

Table 1. Controlled Emission Rates Of Tritium, Argon, and Carbon.

\begin{tabular}{cc}
\hline Radionuclide & Emission rate* $(\mathrm{Ci} / \mathrm{yr})$ \\
\hline${ }^{3} \mathrm{H}$ & 522 \\
${ }^{41} \mathrm{Ar}$ & 0.75 \\
${ }^{4} \mathrm{C}$ & 1.7 \\
\hline
\end{tabular}

* These releases are based on the extremely conservative assumption that the reactor will operate 365 days per year (Section 3.1).

\subsection{PROJECTED POTENTIAL CONTROLLED EMISSIONS}

The projected potential controlled emissions (facility operating $24 \mathrm{~h}$ per day, 365 days per year) for tritium, ${ }^{+} \mathrm{Ar}$, and ${ }^{14} \mathrm{C}$ are equal to the projected actual emissions as set forth in Section 4.2 , above. 
DOE/RL $-90-14$

\subsection{ANTICIPATED CONSTRUCTION SCHEDULE}

The following construction schedule is projected:

$\begin{array}{lr}\text { Start of design (conceptual): } & 6 / 86 \\ \text { Completion of design (definitive): } & 12 / 91 \\ \text { Start of major equipment procurement: } & 4 / 90 \\ \text { Completion of major equipment procurement: } & 6-92 \\ \text { Start of construction: } & 1 / 91 \\ \text { Completion of construction: } & 9 / 93\end{array}$

\subsection{A DEMONSTRATION OF BEST AVAILABLE CONTROL TECHNOLOGY (BACT) SELECTION}

Radionuclides are the only regulated pollutants of concern projected to be emitted by the proposed source in significant quantities, as "significant quantities" are defined by prevention of significant deterioration regulations. Therefore, the demonstration of BACT has been limited to impacts of ambient radionuclide concentrations, or a demonstration of Best Available Radionuclide Control Technology (BARCT).

A BARCT is defined by WAC $402-80-040$ as follows:

Technology which will result in a radionuclide emission limitation based on the maximum degree of reduction for radionuclides which would be emitted from any proposed stationary source or modification of a source which the permitting authority on a case-by-case basis, taking into account energy, environmental, and economic impacts and other costs, determines is achievable for such source or modification through application of production processes or available methods, systems, and techniques. In no event shall application of best available radionuclide technology result in emissions of radionuclides which would exceed the ambient annual standard limitation specified in this chapter.

The emissions control systems described in Section 3.5 are supported as BARCT for the pollutants to be emitted by the SP-100 by the following discussion.

\subsection{CONTROL EQUIPMENT AVAILABLE}

As discussed in Section 2.1, radioactive emissions from the SP-100 test reactor will consist of gaseous radionuclides generated in the PHTS and ACS cover gases; the lithium coolant; and the reactor, pump gallery, and test assembly cell gas. Emissions of particulate matter are not anticipated during either normal operations or shut-down. To identify all possible emission controls, a nuclear and cross-industry survey for tritium and argon (the anticipated PHTS and ACS cover-gas activation product and the reactor, 
pump gallery, and test assembly cell gas activation product) controls was performed (see Appendix A). The controls applicable to each of the three sources of emissions identified are discussed in the following sections.

\subsubsection{Cover Gas}

Releases of radioactive PHTS and ACS cover gas can be controlled by the selection of the cover gas used, by providing decay time before release, and by minimizing the activation of the cover gas. Gases potentially applicable for use as a cover gas include helium (He), oxygen $\left(0_{2}\right)$, nitrogen $\left(\mathrm{N}_{2}\right)$, neon (Ne), xenon (Xe), and argon (Ar). Reducing the gas flow rate via hold-up tanks or increasing the volume of the exhaust ducting are techniques which provide additional decay time before release, and activation of the cover gas can be minimized by providing shielding and by locating the cover gas in areas with a relatively low neutron flux. These options are summarized in Table 2 .

Table 2. Cover Gas Control Alternatives.

\begin{tabular}{ll}
\hline \multicolumn{1}{c}{ Control alternative } & \multicolumn{1}{c}{ Options } \\
\hline Selection of cover gas & $\mathrm{He}$ \\
& $\mathrm{O}_{2}$ \\
& $\mathrm{Ne}_{2}$ \\
& $\mathrm{Xe}$ \\
Providing decay time before release & Reducing gas discharge flowrate \\
& Increasing the volume of exhaust \\
& ducting (holdup system) \\
Minimizing the activation of the & Shielding \\
cover gas & \\
& Location of cover gas expansion \\
& tanks and accumulator tanks \\
\hline
\end{tabular}

The control techniques discussed in the preceding paragraph have been previously studied. Two methods for control of ${ }^{41} \mathrm{Ar}$ were evaluated in a study by the Research Reactor Institute in Osaka, Japan (Kanda 1975). One method evaluated was to reduce the concentration of ${ }^{40} \mathrm{Ar}$ in the air in the reactor room, thereby decreasing the ${ }^{41} \mathrm{Ar}$ production rate. A decrease in the ${ }^{40} \mathrm{Ar}$ concentration produces a corresponding decrease in the ${ }^{41} \mathrm{Ar}$ production rate. The second method studied involved decreasing the reactor room volume, decreasing the ventilation rate, and adding a hold-up tank for attenuation of 
${ }^{41} \mathrm{Ar}$ activity. The ability of a combination of these techniques to achieve a reduction in the ${ }^{41} \mathrm{Ar}$ concentration by a factor of 0.1 or 0.01 was investigated. Actual reductions achieved were not reported.

Control techniques for reducing emissions of air activation products were studied for the proton accelerator at the Los Alamos National Laboratory (Moore 1985). Possible improvements in the beam stop equipment were evaluated to determine their effect on the formation of air activation products. Also studied were the effects of increasing hold-up time on the releases of activation products to the atmosphere. Both extending ducting and adding a hold-up tank to the exhaust system were evaluated.

Another control technique study involved the study of modifications made to the JRR-2 Research Reactor at the Tokai Research Establishment of the Japan Atomic Energy Research Institute to reduce ${ }^{41} \mathrm{Ar}$ emissions

(Miyasaka 1977). Modifications included addition of ${ }^{41} \mathrm{Ar}$ decay ducts and decay tanks. The ${ }^{41} \mathrm{Ar}$ release rate from the JRR-2 stack was reduced from $3.2 \mathrm{Ci} / \mathrm{h}$ to $0.22 \mathrm{Ci} / \mathrm{h}$ with these modifications.

\subsubsection{Tritium Generated Within the Reactor}

Releases of tritium from the reactor can be controlled by selecting an appropriate coolant and by utilizing tritium control technologies.

Potentially applicable coolants include sodium, lithium, and lithium enriched in ${ }^{7}$ Li. Potentially applicable control technologies include reaction of tritium with a metal to form a metal hydride; catalytic hydrogenation of polystyrene; reaction with hydrogen uranyl phosphate (HUP); and reaction of tritium with oxygen to form water and subsequent immobilization by adsorption onto a drying agent, by cement stabilization, or by reaction to form an organic polymer. These options are summarized in Table 3 , and discussed in more detail in the following paragraphs. 
Table 3. Tritium Control Alternatives.

\begin{tabular}{ll}
\hline \multicolumn{1}{c}{ Control alternative } & \multicolumn{1}{c}{ options } \\
\hline Selection of coolant & Sodium \\
Lithium & Lithium enriched in ${ }^{7} \mathrm{Li}$ \\
Tritium control technologies & Reaction with metal to form metal \\
hydride (Getter) & \\
& Catalytic hydrogenation of \\
& polystyrene \\
& Reaction with hydrogen uranyl \\
phosphate & \\
& Reaction to water and subsequent \\
immobilization by adsorption onto & a drying agent, by cement \\
stabilization, or by reaction to \\
form an organic polymer
\end{tabular}

Tritium gas can be immobilized as a solid by the reaction with a suitable metal to form a solid metal hydride:

$$
M+(X / 2)^{3} \mathrm{H}_{2} M^{3} \mathrm{H}_{X}
$$

where:

$$
\begin{aligned}
M & =\text { Symbol for a suitable metal } \\
{ }^{3} H= & \text { Tritium } \\
X= & \text { The number of tritium atoms that combine with each atom of the } \\
& \text { suitable metal. }
\end{aligned}
$$

Many metals react with hydrogen to form solid hydrides, but only transition metals have the desired chemical properties. The properties that make them suitable are very low dissociation pressures at normal temperatures, high capacity for tritium, ease of preparation, and stability in air and water at storage temperatures. The hydrides of zirconium, titanium, hafnium, yttrium, and erbium have been suggested as useful for tritium storage and disposal. Uranium hydride has also been used for many years for short-term storage. However, because uranium hydride is pyrophoric in air, it is less suitable for long-term storage or disposal of tritium (IAEA 1981, IAEA 1984, ERDA 1976). Tests have been performed by the Chalk River Nuclear Laboratories on the preparation of metal hydrides and the physical properties 
DOE/RL $-90-14$

of metal hydrides (Holtslander 1981). Titanium and zirconium hydride were easily formed at room temperature utilizing titanium and zirconium sponges and pure hydrogen. The cumulative fractional releases over a 10 -month period ranged from $10^{-3}$ to $10^{-6}$. The only material currently known to be utilized in commercial applications of this technology is zirconium.

Tritium gas can be fixed by the catalytic hydrogenation of polystyrene over nickel-on-Kieselguhr, Raney nickel, or rhodium-on-alumina catalysts (ERDA 1976).

Nickel-on-Kieselguhr and Raney nickel catalysts require high temperature and high pressure for hydrogenation to proceed. This makes tritium containment difficult. Rhodium-on-alumina catalysts, however, are known to promote hydrogenation of aromatic compounds at atmospheric pressure. Tritiated polystyrene exhibited no measurable activity loss on rinsing or leaching for four to six weeks; however, the polymer is subject to depolymerization and thermal degradation above $280^{\circ} \mathrm{C}\left(536{ }^{\circ} \mathrm{F}\right)$. The upper limit of tritium fixation by this process is $0.5 \mathrm{~g}$ of water treated per gram of polymer. Further development work is required, particularly on the rhodium-on-alumina catalysts.

Hydrogen uranyl phosphate (HUP) has been shown to remove tritium from moist air. This material is a solid ionic conductor which passes electric current as protons instead of electrons. The HUP is pressed between two 316 stainless steel frit disks, one of which has been coated with palladium black, to form a sandwich. A direct current (dc) voltage is applied to the two disks. The disk coated with palladium black is the anode, and the other disk is the cathode. The anode is exposed to the moist air containing tritium. The tritium is believed to be dissociated and oxidized at the anode to form an anion. This tritium anion is attracted through the HUP to the cathode and becomes bound in the hydroxyl network within the HUP. Therefore, the tritium is in the "water" form within the HUP. In addition, $10 \%$ of the tritium entering the control equipment is converted to tritiated water (Souers 1985, Souers 1984). This is an unwanted side reaction. Further development work is considered necessary for this experimental technology.

Tritium gas can be catalytically oxidized to tritiated water. Several different catalysts are currently being used. These are palladium and platinum catalysts of proprietary composition supplied by Englehard and Company, hopcalite which is composed of $\mathrm{CuO}$ and $\mathrm{MnO}_{2}$, and pure platinum catalyst (IAEA 1984, IAEA 1981). The tritiated water that is formed must then be immobilized by one of several available techniques. Drying agents considered applicable to immobilization of tritiated water include activated alumina, silica gel, calcium sulfate, and molecular sieves. Combination of the tritiated water with various commercial cements is another method of immobilization. Cements have a high capacity for water, from $25 \%$ for Portland cement to $50 \%$ for high-alumina cements. Polymeric materials considered for tritium fixation and storage include polyacetylene, bakelite analogues, and polyacrylonitrile. Oxidation of tritium to tritiated water with subsequent adsorption onto a molecular sieve is the most commonly used tritium control strategy. This technique has been used at Mound Research Corporation, General Electric Company, Lawrence Livermore National Laboratory, Los Alamos National 
Laboratory, KMS Fusion, Savannah River Plant, Ontario Hydro, Brookhaven National Laboratory, and Princeton Plasmic Physics Laboratory (Shor 1988, Wieneke 1988, ERDA 1976).

\subsubsection{Reactor/Pump Gallery/Test Assembly Cell Gas}

Releases of radioactive reactor and test assembly cell gas can be controlled by the selection of the gas used, by providing decay time before release, and by minimizing the activation of the cell gas. Gases potentially applicable for use in the cells include $\mathrm{O}_{2}, \mathrm{~N}_{2}$, He, $\mathrm{Ne}, \mathrm{Xe}$, and $\mathrm{Ar}$. Reducing the gas flow rate or increasing the volume of exhaust ducting are techniques which provide additional decay time before release, and activation of the cell gas can be minimized by providing shielding. These options are summarized in Table 4. See Section 6.1.1 for additional details on previous studies of these control options.

Table 4. Cell Gas Control Alternatives.

\begin{tabular}{ll}
\hline \multicolumn{1}{c}{ Control alternative } & \multicolumn{1}{c}{ Option } \\
\hline Selection of gas & $\mathrm{O}_{2}$ \\
& $\mathrm{Ne}$ \\
& $\mathrm{Ne}$ \\
& $\mathrm{Ar}$ \\
Providing decay time before & Reducing gas discharge flowrate \\
release & $\begin{array}{l}\text { Increasing the volume of exhaust } \\
\text { ducting (hold-up system) }\end{array}$ \\
$\begin{array}{l}\text { Minimizing activation of the } \\
\text { cell gas }\end{array}$ & Shielding \\
\hline
\end{tabular}

\subsection{CONTROL ALTERNATIVES}

\subsubsection{Cover Gas}

As shown in Table 2, He, $\mathrm{O}_{2}, \mathrm{~N}_{2}$, $\mathrm{Ne}$, Xe, and Ar are available for use as the cover gas. The use of oxygen as the cover gas would be unacceptable because it would result in a lithium or sodium fire. Nitrogen would also be unacceptable because it would react with the lithium or the sodium and would therefore contaminate the coolant and embrittle the core structure materials and fuel cladding. Xenon was el iminated because of the long-lived activation products that are formed. Xenon-134 and ${ }^{136} \mathrm{Xe}$, naturally occurring isotopes of Xenon, activate to form ${ }^{135} \mathrm{Xe}$ and ${ }^{137} \mathrm{Xe}$, respectively. Xenon-135 decays 
to ${ }^{135} \mathrm{Cs}$ which has a $3 \times 10^{6}$ yr half-life, and $137 \mathrm{Xe}$ decays to ${ }^{137} \mathrm{Cs}$ which has a 30.17-yr half-life. Since helium does not activate, it is considered a viable option. Neon-23 and ${ }^{22} \mathrm{~F}$, activation products of neon, have half-lives of $37.6 \mathrm{~s}$ and $4.23 \mathrm{~s}$, respectively. Argon-4l, the activation product of naturally occurring ${ }^{40} \mathrm{Ar}$, has a $1.83-\mathrm{h}$ half-life. Both neon and argon have relatively short half-lives and are therefore also considered to be technically feasible alternatives.

As discussed in Section 6.1.1, radioactive emissions can be reduced by providing additional decay time before release. Additional decay time can be provided by reducing the exhaust gas flow rate, increasing the volume of the exhaust ducting, or both. The largest reduction in radionuclide emissions can be achieved by reducing the exhaust gas flow rate to zero while the reactor is operating, or in other words, using a sealed system. A sealed system is a system that under normal operating conditions is totally isolated from the environment. Therefore, there are no inputs or outputs to the system while the reactor is operating. This does not mean that the cover gas will be held indefinitely in the reactor. However, the cover can be held for a relatively long period of time to allow the activation products to decay to stable atoms once the reactor is shut down and the neutron source which causes activation is eliminated. This will provide a hold-up time much greater than can be provided by either reducing the flow rate of the exhaust gas while the reactor is operating or by increasing the volume of exhaust ducting. Therefore, a sealed system which provides a minimum of 6 -month decay time before release was chosen as BARCT. No further analysis of this issue will be performed.

Additional provisions for pressure control other than the use of expansion tanks are necessary when a sealed system is used. Specifically, accumulator tanks are provided for this additional pressure control. The location of the accumulator tank for the PHTS is shown in Figure 8 . The cover gas in the expansion tanks will be connected to the cover gas in the accumulator tanks via two pipes. The combination expansion tanks and accumulator tanks will be sized to maintain an acceptable pressure in the system at all times.

The activation of the cover gas can be minimized by providing appropriate shielding and by locating the expansion tanks and the accumulator tanks, which contain the cover gas, in areas of low neutron flux. Both of these options have been incorporated into the SP-100 design. Shielding located between the upper and lower vacuum vessel (labeled upper internal facility shield in Figure 3 ) reduces the activation of the cover gas in the PHTS expansion tank and the ACS expansion tank. The accumulator tanks which contain the majority of the cover gas are located outside of the vacuum vessel in an area of low neutron flux (not shown in any of the figures). Since both options identified for controlling activation of the cover gas are utilized with this design, the design is considered BARCT. 
Because the sealed cover gas system, shielding, and the location of the expansion tanks and accumulator tanks are considered BARCT, further analysis of these components of the cover gas system was not undertaken. However, further analysis of the cover gas alternatives - - helium, neon, and argon -. will be necessary. This analysis is presented in Section 6.3.

\subsubsection{Tritium Generated Within the Reactor}

Sodium, lithium, and 1 ithium enriched in ${ }^{7} \mathrm{Li}$ are available for use in the primary heat transport system (see Table 3 ). If Tithium is used as the primary coolant, the reactor can be operated at a higher temperature than if sodium is used. Therefore, the thermal efficiency of the reactor is higher, and the reactor generates more electricity. For this reason, 1 ithium was determined to be superior from an operating standpoint, and sodium was dropped from further consideration. However, tritium is formed by the activation of ${ }^{6} \mathrm{Li}$. To reduce the formation of tritium, lithium which has been enriched in ${ }^{7} \mathrm{Li}$ (which does not neutron-activate to form tritium) could be used. Since lithium enriched in ${ }^{7} \mathrm{Li}$ is readily available, it will be used in the reactor. This option is considered BARCT, and no further analysis of a) ternative coolants will be performed.

As discussed in Section 6.1.2, tritium emissions can be controlled by using one of the following control technologies: reaction of tritium with a metal to form a metal hydride; catalytic hydrogenation of polystyrene; reaction with HUP; and reaction of tritium with oxygen to form water and subsequent immobilization by adsorption onto a drying agent, by cement stabilization, or by reaction to form an organic polymer. Catalytic hydrogenation of polystyrene was el iminated from further consideration for several reasons. First, this technology has not been tested to determine its effectiveness in controlling tritium emissions. Second, most development work has been done on catalysts that operate at high temperature and pressure. Operating at high temperature and pressure complicates both tritium containment and control of the process in a contaminated zone (ERDA 1976). Reaction of tritium with HUP was also el iminated from further consideration. The primary reason for this is that the technology is considered too developmental. Only two reports on the HUP concept, both published by researchers at Lawrence Livermore National Laboratory (Souers 1984, Souers 1985) were identified during the literature survey. The experiments performed at Lawrence Livermore Laboratory were on laboratory-scale equipment. Full-scale equipment has not been developed or tested. The second reason for eliminating HUP from further consideration is that the technology generates tritiated water. This is an unwanted side reaction, and controlling the tritiated water that is generated would be an added complication.

Reaction of tritium with a metal to form a metal hydride and reaction with oxygen to form water with subsequent immobilization are considered viable alternatives. The option consisting of reaction with oxygen to form water and subsequent immobilization requires further refinement. This is discussed in the following paragraphs. 
Once the tritium gas has been converted to water by catalytic oxidation, there are many options available for dealing with the tritiated water. These options include adsorption onto one of several different drying agents which include activated alumina, silica gel, calcium sulfate, and molecular sieves (ERDA 1976). Activated alumina and silica gel have high water capacities; however, they only bind water strongly at low loadings. Calcium sulfate has the advantage of low cost, but its water capacity is low. Molecular sieves exhibit high water capacities, and they retain their desiccant properties at temperatures higher than those for other adsorbents. Molecular sieves are therefore the drying agent of choice for this application.

The second option for dealing with the tritiated water is immobilization by cement stabilization. Although cement is relatively inexpensive, the leach rate of tritium from cement is high (IAEA 1981). Therefore, cement stabilization is not considered a viable option.

The last option applicable to immobilization of tritiated water is reaction to form an organic polymer (IAEA 1981). Polymers considered include polyacetylene, bakelite analogues, and polyacrylonitrile. These compounds have a low volatility, are chemically stable, and exhibit hydrophobic properties. Very few tests on leach rates have been performed, and these compounds may be susceptible to radiation damage. In addition, these techniques for immobilization have not been demonstrated. Therefore, the best option currently available for immobilization of tritiated water is adsorption on molecular sieves.

As discussed above, further analysis of primary coolant alternatives is not necessary. Lithium enriched in ${ }^{7} \mathrm{Li}$ will be used. A BARCT analysis of tritium control alternatives, which includes no controls, reaction with metal to form a metal hydride, and reaction with oxygen to form water and subsequent immobilization on a molecular sieve, is necessary. This analysis is presented in Section 6.3.2.

\subsubsection{Reactor/Pump Gallery/Test Assembly Cell Gas}

As shown on Table $4, \mathrm{O}_{2}, \mathrm{~N}_{2}$, $\mathrm{He}, \mathrm{Ne}, \mathrm{Xe}$, and $\mathrm{Ar}$ are available for use as the reactor and test assembly cell gas. Of the six alternatives, three are unacceptable for technical reasons. Using oxygen as the cell gas would be unacceptable because of the reactivity of pure oxygen. Helium was eliminated from further consideration because of its ability to pass through extremely smal1 openings and the difficulty experienced in pumping it. Inherent leaks in the vacuum vessel would be approximately four times worse with helium than argon because of its ability to pass through extremely small openings. Once helium has leaked into the vacuum vessel, it would be difficult to remove because helium is difficult to pump. Maintaining a high vacuum would be difficult, therefore, if not impossible, using the current vacuum vessel and system design. Xenon was eliminated from further consideration because of the long-lived activation products that are formed. Xenon-134 and $136 \times e$, naturally occurring isotopes of xenon, activate to form $135 \mathrm{Xe}$ and $137 \mathrm{Xe}$, respectively. Xenon-135 decays to ${ }^{135} \mathrm{Cs}$ which has a $3 \times 10^{6}$ yr half-life, 
and $137 \mathrm{Xe}$ decays to ${ }^{137} \mathrm{Cs}$ which has a $30.17-y r$ half-life. Although nitrogen activates to form a long-lived activation product, $1{ }^{4} \mathrm{C}$; it is still considered a viable alternative because the activation rate is relatively low. Neon and argon activate to form only short-lived activation products. Therefore, neon and argon are also considered viable alternatives.

The reactor cell gas is located in an area of high neutron flux. The addition of a near-reactor shield around the guard vessel (Figure 3 ) can be used to reduce the neutron flux and therefore reduce the quantity of radioactive contaminants generated. However, the design of a near-reactor shield requires water. Water in the near-reactor shield is a major safety concern. Because water acts as a moderator, there is a potential of reaching criticality in the event of a reactor accident and failure of the redundant safety systems. Therefore, using a near-reactor shield is not a viable option and further consideration of it was not undertaken.

Because a sealed system is used in the design and the use of a near reactor shield was shown to present safety considerations, further analysis of these issues was not undertaken. However, further analys is of the reactor cell gas alternatives -- nitrogen, neon and argon -- will be necessary. This analysis is presented in Section 6.3.3.

\subsection{BEST AVAILABLE RADIONUCLIDE CONTROL TECHNOLOGY}

\subsubsection{Cover Gas}

As discussed in Section 3.5, the PHTS and ACS cover gas systems will be sealed, shielding will be provided to minimize activation of the cover gases, and the expansion and accumulator tanks will be located in areas of low neutron flux. These design options are considered BARCT, and no further analysis of these options will be performed. The BARCT analys is will be limited to evaluation of three alternative reactor cover gases: helium, neon, and argon.

6.3.1.1 Environmental. Since helium does not activate, radioactive emissions would be eliminated if helium is used as the reactor cover gas. Neon forms $23 \mathrm{Ne}$ and $22 \mathrm{~F}$ by neutron activation. These isotopes have half-lives of $37.6 \mathrm{~s}$ and $4.23 \mathrm{~s}$, respectively. Argon-40 activates to form ${ }^{41} \mathrm{Ar}$, which has a 1.83 -h half-life. The radioactivity of any material is reduced by a factor of 1000 if allowed to decay for 10 half-lives. Therefore, essentially no radioactivity will remain in the reactor cover gas after holding the gas for 7 min if neon is used and $18 \mathrm{~h}$ if argon is used. The reactor cover gas will actually be held for a minimum of 6 months after the reactor has been shut down and the neutron source has been eliminated. This is sufficiently long for both neon and argon that releases will be essentially zero for the two gases. Thus, no distinction exists between the three gases from an environmental standpoint.

6.3.1.2 Energy. An analysis of energy requirements is not applicable to the selection of a cover gas in determining the BARCT. 
6.3.1.3 Economic. Argon costs $\$ 0.50 / \mathrm{L}$ of cryogenic liquid. This value is based on the present cost for argon at the Fast Flux Test Facility (FFTF). Argon is routinely used at the Hanford Site and is readily available. Helium cost is somewhat higher than argon cost based on the cost of the helium used when $\mathrm{N}$ Reactor was operating $2 \mathrm{yr}$ ago. The only source of large quantities of pure helium is the U.S. Bureau of Mines in Texas. Neon costs approximately $\$ 157 / \mathrm{L}$ of cryogenic liquid, based on discussion with a major vendor. Although the conversion from liquid to gas is approximately $60 \%$ better for neon than for argon, neon would still be much more expensive.

6.3.1.4 Summary. Helium, neon, and argon are equally suitable for use as the reactor cover gas. From an environmental standpoint, they are essentially identical. The planned hold-up time of 6 months will allow activated cover gases to decay to near zero activity. Argon was chosen therefore as the reactor cover gas because it costs less than helium and neon and because it is readily available from numerous suppliers.

\subsubsection{Tritium Generated Within the Reactor}

As discussed in Section 6.2.2, tritium production will be significantly reduced by using lithium enriched in ${ }^{7} \mathrm{Li}$. This design option is considered BARCT, and no further analysis of coolant options will be performed. The BARCT analysis will be 1 imited to evaluation of the no-controls alternative and the two tritium control technologies: reaction with metal to form a metal hydride and reaction with oxygen to form water and subsequent immobilization on a molecular sieve. In the following paragraphs, more detailed information is provided on the tritium control systems to be evaluated.

\section{Zirconium Getters}

Once the vacuum vessel is evacuated, cryopumps are used to collect the tritium generated within the vacuum vessel. The cryopumps use a refrigeration mechanism capable of lowering temperatures below which atmospheric gases and hydrogen gas will condense. Tritium that is regenerated from the cyropumps or pumped through the roughing system turbo pumps is passed to the getter beds. The getter beds contain a zirconium alloy that has a high affinity for hydrogen and other active gases. As the tritium flows over the zirconium alloy a surface reaction takes place which tritium diffuses into the metal matrix and forms zirconium tritide ( $\mathrm{ZrT}$ ). The zirconium alloy utilized is zirconium-vanadium-iron ( $\mathrm{Zr}-\mathrm{V}-\mathrm{Fe})$. This alloy has a low operating temperature of about $150{ }^{\circ} \mathrm{C}$ for optimum performance.

The zirconium has to be pre-activated by heating the getter bed to $500-600{ }^{\circ} \mathrm{C}\left(932-1112{ }^{\circ} \mathrm{F}\right)$ under a vacuum to drive off gettered gases before installation. This activation is done by the supplier but could be done onsite. The getter material is then fixed into a removable canister so that as the getter becomes saturated ( $50 \%$ of theoretical capacity) the canister can be removed and a fresh canister installed. 
For the SP-100 system, a series-parallel set of getter beds is proposed. This system consists of primary and secondary getters in series and a parallel set for operational redundancy. The getter beds are isolated individually by bellows sealed valves. By suitable valving, the tritium process gas can be passed through either primary getter and then to either secondary getter.

The system contains a number of tritium monitors to measure the amount of tritium passing through each stage. The tritium monitors are ionization detectors specifically calibrated for tritium. A mass flowmeter is also installed to measure the amount of tritium passing through the system. A detector is also installed at the exhaust of the secondary getter. If this detector shows a level of tritium higher than a preset level, the gas stream is then recycled back to the primary getter. This recycle continues until proper tritium levels are achieved. The gas stream is then passed to the containment exhaust system.

The decontamination factor, DF, for two stages of getter beds is 14,500 (assumes $0.75 \mathrm{~kg}$ of $\mathrm{Zr}-\mathrm{V}-\mathrm{Fe}$ ), i.e., for every curie of tritium that enters the getter, $1 / 14,500 \mathrm{Ci}$ exit. Therefore, for the $1.43 \mathrm{Ci} /$ day of tritium generated at the SP-100 site, $1.0 \times 10^{-4} \mathrm{Ci} /$ day would be released. The decontamination factor is not constant at extremely low tritium levels and as saturation capacity is approached; therefore the recycle feature would be an added safety feature.

\section{Reaction With Oxygen/Molecular Sieve}

Once the vacuum vessel has been evacuated, cryopumps are used to collect the tritium generated within the vacuum vessel. The cryopumps use a refrigeration mechanism capable of lowering temperatures below which atmospheric gases and hydrogen gas will condense. Tritium that is regenerated from the cryopumps or pumped through the roughing system pumps is passed to the tritium handling system. The effluent from the vacuum system is collected in a low-pressure receiver until pressure reaches $14 \mathrm{lbf} / \mathrm{in}^{2}$ actual. A preheater is utilized at the front end of the catalytic reactor to raise the process gas temperature to $175^{\circ} \mathrm{C}\left(347^{\circ} \mathrm{F}\right)$. The gas is then pumped through a catalytic reactor, where tritium containing species are oxidized at $450{ }^{\circ} \mathrm{C}\left(842^{\circ} \mathrm{F}\right)$ to water vapor. Following the reactor, the tritiated water vapor is first cooled in a heat exchanger to $12.2{ }^{\circ} \mathrm{C}\left(54^{\circ} \mathrm{F}\right.$ ) and then stripped out in molecular sieve beds. Process ionization chambers monitor tritium passing the molecular sieves and recycle the gas stream if tritium removal is not complete. Finally, the process gas stream is allowed to pass to the containment exhaust.

The catalytic reactor contains either palladium or platinum on an alumina substrate (i.e., palladium-coated alumina pellets). Excess oxygen has to be added to the reactor bed to allow for the catalytic reaction to take place (this assumes that the process gas is predominantly argon or helium). The catalytic reaction is exothermic, and therefore the gas temperature is raised to $450{ }^{\circ} \mathrm{C}\left(842^{\circ} \mathrm{F}\right)$ in the reactor. The molecular sieves have a high surface area for adsorption and are hydrophilic, i.e., preferentially adsorbing 
water. The molecular sieves are commercially produced porous crystalline alumino silicates (Type 4A). The molecular sieves will be placed in canisters and will be removed as the capacity limit is achieved.

This system is envisioned to consist of two separate parallel process streams for operational redundancy. Each process stream has two molecular sieve beds in series.

6.3.2.1 Environmental. The tritium control alternatives can be designed to achieve the same removal efficiency by incorporating recycle or redundant systems. The tritium emission rate will be $1.0 \times 10^{-4} \mathrm{Ci} /$ day if either one of the tritium control alternatives is used. (This emission rate is equivalent to a $2.2 \times 10^{-6} \mathrm{mrem} / \mathrm{yr}$ dose.) Therefore, the two tritium control alternatives are indistinguishable from the standpoint of gaseous emissions control. However, the alternatives are distinguishable when other environmental factors are taken into account.

One factor which is particularly important is the form in which tritium is immobilized. When tritium reacts with a transition metal, such as zirconium or titanium, the tritium is incorporated directly into the metal matrix in the form of a hydride. In the second option, where the tritium is oxidized catalytically to water and then immobilized on a molecular sieve, the tritium is immobilized in the "water" form. Since tritiated water is more active biologically than tritium gas, tritium immobilized in the hydride form poses a much smaller threat to human health than tritium immobilized in the water form.

The second important environmental factor is the tritium leach rate from the immobilized form. Samples of tritiated zirconium hydride were leached in distilled water, saturated $\mathrm{KCl}$ and $\mathrm{NaCl}$ solutions, aqueous $\mathrm{NaOH}$, and $\mathrm{HCl}$ for over $1 \mathrm{yr}$ (ERDA 1976). The maximum fractional activity release over this period was $5 \times 10^{-4}$ in the $\mathrm{NaOH}$ solution. It should be noted that the sample was pulverized by a stirring bar before the test, and the increased surface area presumably contributed significantly to the leach rate. The fractional leach rate of tritium from a molecular sieve encapsulated in polystyrene was on the order of $1.0 \times 10^{-3}$ to $1.0 \times 10^{-4}$ per day (ERDA 1976). This is significantly higher than the leach rate from the metal hydride, especially when the form of the material leach tested is considered.

Taking into account these two environmental factors, immobilizing tritium in the form of a metal hydride is the best available alternative. Metal hydrides have the lowest demonstrated leach rate, and they also immobilize tritium in the less hazardous hydride form.

The tritium emission rate will be approximately $1.4 \mathrm{Ci} /$ day if no tritium controls are utilized. (This emission rate is equivalent to a

$3.1 \times 10^{-2} \mathrm{mrem} / \mathrm{yr}$ dose.) Therefore, from an environmental standpoint, no controls is the least favored alternative. However, the no-controls option does not result in the production of solid waste as do the other two alternatives. Even so, immobilization of tritium in the form of a metal hydride is still considered the best alternative based solely on environmental considerations. 
6.3.2.2 Energy. The no-controls alternative requires no energy. The energy requirements for the tritium control system using zirconium getters will be relatively low. The pumps used to recycle the process streams are the only process units that require the input of energy. The estimated power consumption for these pumps is approximately $860 \mathrm{~W}$. The energy requirements for the tritium control system using catalytic reactors and molecular sieves will be higher than the system which uses zirconium getters. The main energy users in this system are the pumps used to recycle the process streams, the preheater, and the chilled water pump. The estimated power consumption for these process units is approximately $1,600 \mathrm{~W}$.

6.3.2.3 Economic. The capital cost for the tritium control system using zirconium getters is estimated to be approximately $\$ 3,046,000$. The capital cost for the system utilizing catalytic reactors and molecular sieves will not be significantly different from the cost for the zirconium getters. The cost of operating and maintaining the two systems is shown in Table 5 . Again, there are no significant differences in the operating cost. The total cost of either one of the control alternatives is therefore approximately $\$ 3,090,800$. There are no economic costs associated with the no-controls alternative.

Table 5. Costs For Tritium Control Alternatives.

\begin{tabular}{lccc}
\hline \multicolumn{1}{c}{ Cost (in \$) } & $\begin{array}{c}\text { Zirconium } \\
\text { getters }\end{array}$ & $\begin{array}{c}\text { Catalytic reactor } \\
\text { molecular sieve }\end{array}$ & No controls \\
\hline $\begin{array}{l}\text { Capital cost } \\
\text { Operating cost } \\
\text { Electrical }\end{array}$ & $3,046,000$ & $3,046,000$ & 0 \\
$\begin{array}{l}\text { Replacement getters } \\
\text { Maintenance }\end{array}$ & 10,000 & 117 & \\
Operations & 12,800 & 10,000 & 12,800 \\
Total* & $\underline{21,900}$ & $\underline{21,900}$ & 0 \\
TOTAL COST & 44,763 & 44,817 & 0 \\
\hline
\end{tabular}

*This represents the total operating cost for the life of the project (assumed to be $2 \mathrm{yr}$ ).

6.3.2.4 Summary. The total cost associated with the use of tritium getters is approximately $\$ 3$ million. Application of this technology is anticipated to reduce the dose to the maximally exposed offsite individual from $3.1 \times 10^{-2} \mathrm{mrem} / \mathrm{yr}$ to $2.2 \times 10^{-6} \mathrm{mrem} / \mathrm{yr}$. The cost, then, of the application of this control technology would be approximately $\$ 100$ billion per rem of exposure to the maximally exposed offsite individual (Table 6). 
$\mathrm{DOE} / \mathrm{RL} 90-14$

Table 6. Comparison of Tritium Controls.

\begin{tabular}{|c|c|c|}
\hline with & $H$ controls & Without $H$ controls \\
\hline $\begin{array}{l}{ }^{3} \mathrm{H} \text { emissions } \\
(\mathrm{Ci} / \text { day })\end{array}$ & $1.0 E-04$ & 1.43 \\
\hline $\begin{array}{l}\text { Dose to maximally } \\
\text { exposed individual } \\
\text { (mrem/yr) }\end{array}$ & $2.15 E-06$ & 0.031 \\
\hline $\begin{array}{l}\text { Natural ambient } \\
\text { radiation } \\
\text { (mrem/yr) }\end{array}$ & 300 & 300 \\
\hline Capital costs $(\$)$ & $3,100,000$ & 0 \\
\hline $\begin{array}{l}\$ / \text { rem reduction } \\
\text { in offsite dose }\end{array}$ & $100,000,000,000$ & 0 \\
\hline
\end{tabular}

Because the dose to the public from the project and from all other sources at the Hanford Site, is much lower than the levels set by The Environmental Protection Agency (EPA) for an acceptable risk under National Emissions Standards for Hazardous Air Pollution (NESHAP) (Section 9.0), no additional control of tritium beyond the use of lithium coolant enriched with ${ }^{7} L i$ is a viable option. The reduction in the dose achieved by the tritium control systems cannot be justified given the high cost of these controls relative to the decrease in radionuclide exposure to the population. The no-control option for tritium is considered BARCT.

\subsubsection{Reactor/Pump Gallery/Test Assembly Cell Gas}

As discussed in Section 3.5, radioactive emissions from the cell gas system will be controlled by utilizing a sealed system. This design option is considered BARCT, and no further analysis of this option will be performed. In addition, no further analysis of the near reactor shield will be performed because of safety-related reasons discussed in Section 6.2.3. The BARCT analysis will be limited therefore to evaluation of the three alternative reactor cell gases.. nitrogen, neon, and argon.

6.3.3.1 Environmental. The half-lives of ${ }^{4} \mathrm{C}$ and ${ }^{15} \mathrm{~N}$, the activation products of nitrogen, are $5,730 \mathrm{yr}$ and $7.1 \mathrm{~s}$, respectively. The half-life of ${ }^{4} \mathrm{Ar}$, the activation product of ${ }^{1 \mathrm{Ar}} \mathrm{Ar}$, is $1.83 \mathrm{~h}$. The half lives of $\mathrm{Ne}$ and $22 \mathrm{~F}$, the activation products of neon, are $37.6 \mathrm{~s}$ and $4.23 \mathrm{~s}$, respectively. Since the activation products of neon have much shorter half-lives than the activation products of argon and nitrogen, radioactive emissions from the cell gas system would be the least if neon were used. However, the DCG could be met if argon $\left(1.0 \times 10^{\circ} \mathrm{uCi} / \mathrm{mL}\right)$ were used for the pump gallery and test assembly cell. The discharge limit would probably not 
be met if argon were used in the reactor cell because the reactor cell gas is exposed to a higher neutron flux than the other two cells and because argon activates readily. The $D C G$ for ${ }^{4} \mathrm{C}\left(5 \times 10^{;} \mathrm{uCi} / \mathrm{mL}\right.$ of air $)$ would be met if nitrogen were used as the reactor cell gas.

6.3.3.2 Energy. An analysis of energy requirements is not applicable to the selection of a reactor cell gas.

6.3.3.3 Economic. The nitrogen cost is $\$ 0.11 / \mathrm{L}$ of cryogenic 1iquid. Argon costs $\$ 0.50 / \mathrm{L}$ of cryogenic liquid. This value is based on the present cost for argon at FFTF. Both nitrogen and argon are routinely used at the Hanford Site and are readily available. Neon costs approximately $\$ 157 / \mathrm{L}$ of cryogenic liquid according to one vendor. Although the conversion from liquid to gas is approximately $60 \%$ better for neon than for argon, neon would still be much more expensive. Neon is also much more expensive than nitrogen. In addition, the quantity of neon that would be required could exceed the vendor's ability to produce it.

6.3.3.4 Summary. Although neon would result in a lower radioactive emission rate, its cost is prohibitive and sufficient production capacity may not be available. Because the DCG would be met if argon were used in the pump gallery cell and test assembly cell and nitrogen were used in the reactor ce11, argon and nitrogen are chosen as the cell gases. Nitrogen does react with the $\mathrm{Nb}-\mathrm{Zr}$ alloy at high temperatures, and its use will involve the risk of damaging the reactor if a leak develops into the vacuum vessel. Because there is a minimum of penetrations and only one sealed flange in the vacuum vessel within the reactor cell, this risk is considered acceptable.

\subsection{ANALYSIS OF PRESENT AIR QUALITY AT THE PROPOSED SOURCE LOCATION}

Radionuclides are the only regulated pollutants of concern projected to be emitted by the proposed source in significant quantities, as "significant quantities" are defined by PSD regulations. Therefore, the analysis of present air quality at the proposed source location has been limited to impacts of ambient radionuclide concentrations.

Data used to develop the Hanford Site Environmental Report for Calendar Year 1988 (Jaquish 1989) show that radiological airborne emissions from the proposed project site (300 Area) for calendar year 1988 totaled approximately $3.2 \times 10^{-4} \mathrm{mrem}$. This dose can be compared to regulatory limits set by WAC 402-80-50, WAC 173-480-040, and 40 CFR 61.92.

Both WAC 402-80-50 and WAC 173-480-040 state the following:

The WDOE ambient standard requires that emissions of radionuclides to the air shall not cause a dose equivalent of more than $25 \mathrm{mrem} / \mathrm{yr}$ to the whole body or $75 \mathrm{mrem} / \mathrm{yr}$ to a critical organ of any member of the public. 
National ambient air quality standards for DOE facilities, are stated in 40 CFR 61.92 as follows:

Emissions of radionuclides to the ambient air from Department of Energy facilities shall not exceed those amounts that would cause any member of the public to receive in any year an effective dose equivalent of $10 \mathrm{mrem} / \mathrm{yr}$.

The average dose to the maximally exposed offsite individual from 300 Area airborne emissions in 1988 was less than $0.01 \%$ of the most stringent regulatory limit.

\subsection{ANALYSIS OF THE PROPOSED SOURCE ON AMBIENT AIR QUALITY}

Again, radionuclides are the only regulated pollutants of concern projected to be emitted by the proposed source in significant quantities, as "significant" is defined by PSD regulations. Therefore, the analysis of the impact of the emissions from the proposed source on ambient air quality has been 1 imited to impacts of projected ambient radionuclide concentrations.

\subsection{MODEL DESCRIPTION}

The AIRDOSE-EPA ("Clean Air Act Code") computer code was used to calculate the dose from the SP-100 to the maximally exposed offsite individual.

Meteorological data input to the AIRDOSE-EPA code include mixing height, rainfall rate, average air temperature, vertical temperature gradient, wind direction frequency, wind speed, and atmospheric stability. This information was obtained from the database compiled by the Hanford Meteorological Station (HMS). The HMS data on airspeed, direction, and temperature are collected at a $61 \mathrm{-m}(200-\mathrm{ft})$ tower located on the Hanford Site near the southwest corner of the 300 Area. Wind speed and direction are based on hourly data collected at the 300 Area meteorological tower $10-\mathrm{m}(32.8-\mathrm{ft})$ level during the years 1983 to 1987 . Atmospheric stability was estimated from the temperature gradient between the $9.1-\mathrm{m}(30-\mathrm{ft})$ and $61 \mathrm{-m}(200-\mathrm{ft})$ levels at the tower for the same period using standard methods of the U.S. Nuclear Regulatory Commission (NRC). Air temperature and mixing height are also 5-yr averages of hourly data. Temperature is measured at the tower 61-m (200-ft) level, and mixing height data are collected by onsite acoustic sounders.

Joint frequency data, as reported by the HMS, are modified for input into AIRDOSE-EPA by conversion to true average and reciprocal average wind speeds for each direction and stability class. The meteorological data are then used to calculate $X / Q$ values for each radionuclide, which are also a function of radiological half-life and dry deposition velocity. For purposes of this 
calculation, deposition velocities are assigned as follows:

$1.0 \times 10^{-3} \mathrm{~m} / \mathrm{s}$ for all particulate materials, $1.0 \times 10^{-3} \mathrm{~m} / \mathrm{s}$ for iodine isotopes, and 0 for all gases.

Source Terms: Projected annual releases from SP-100 as presented in Table 7 .

Release Height: The SP-100 stack height is $30.5-\mathrm{m}(100 \mathrm{ft})$.

Inhalation Rate: $8,500 \mathrm{~m}^{3} / \mathrm{yr}$.

Maximally Exposed Individual: Doses were estimated for an individual living $5.6 \mathrm{~km}$ (9 mi) south of the 309 Building.

Meteorology: Hanford Meteorological Station data and onsite meteorological data, as discussed above.

Table 7. Offsite Dose Estimates for an Individual Receiving Maximum Exposure to Airborne Radiological Emissions From SP-100 (mem/yr).

\begin{tabular}{ccc}
\hline Radionuclide & Whole body & Critical organ (thyroid) \\
\hline${ }^{14} \mathrm{C}$ & $1.8 \mathrm{E}-02$ & $2.1 \mathrm{E}-02$ \\
${ }^{3} \mathrm{H}$ & $3.1 \mathrm{E}-02$ & $3.0 \mathrm{E}-02$ \\
${ }^{4}{ }^{\mathrm{A}} \mathrm{Ar}$ & $2.8 \mathrm{E}-05$ & $3.5 \mathrm{E}-05$ \\
Total & $4.9 \mathrm{E}-02$ & $5.1 \mathrm{E}-02$ \\
\hline
\end{tabular}

\subsection{RESULTS OF MODELING ANALYSIS}

Table 7 shows that the projected doses from SP-100 controlled airborne radiological emissions to the maximally exposed offsite individual are $0.05 \mathrm{mrem}$ to the whole body, and $0.05 \mathrm{mrem}$ to the critical organ. The whole body dose attributable to radiological emissions from SP-100 will constitute, then, approximately $0.5 \%$ of the 40 CFR 61.92 Effective Dose Equivalent regulatory limit of 10 mrem to the maximally exposed offsite individual, and only $0.2 \%$ of the WAC $402-80-050$ regulatory 1 imit.

The natural background radiation dose for the Tri-Cities area of Washington State is estimated to be $300 \mathrm{mrem}$ (Jaquish 1989). The projected dose from the SP-100 would constitute $0.02 \%$ of natural ambient radiation. 


\subsection{DEMONSTRATE THAT PROPOSED EMISSIONS WILL NOT CAUSE A VIOLATION OF STATE OR NATIONAL AMBIENT AIR QUALITY STANDARDS}

Total 1988 airborne radiological emissions from the Hanford Site resulted in 0.3 mrem whole body dose to the maximally exposed offsite individual (Jaquish 1989). If the projected airborne radionuclide dose from SP-100 to the maximally exposed offsite individual, as 1 isted in Table 7 , is added to the historic releases for 1988, it is clear that SP-100 emissions will not cause a violation of either state or federal standards (Section 7.0).

\subsection{DEMONSTRATE THAT PROPOSED EMISSIONS WILL NOT CAUSE AN EXCURSION OVER PSD INCREMENTS FOR PARTICULATE MATTER AND SULFUR DIOXIDE}

No sulfur dioxide will be emitted by SP-100; therefore the PSD sulfur dioxide increments are not applicable.

Because the proposed project will not meet "significant" emission levels for particulate matter, as significant emission levels are defined by 40 CFR 52.21, no air-quality impact analyses are required for particulate matter.

\subsection{DEMONSTRATE THAT PROPOSED EMISSIONS WILL NOT IMPAIR VISIBILITY IN A CLASS I AREA OR OTHER SENSITIVE AREAS}

The 40 CFR 52.21 states that demonstrations of visibility impact are not required for sources not within $10 \mathrm{~km}$ of a Class I Area. The proposed source will not be constructed within $10 \mathrm{~km}$ of a Class I Area.

\subsection{DISCUSS THE PROPOSED PROJECT'S EFFECTS ON \\ RESIDENTIAL OR COMMERCIAL GROWTH, VEHICULAR \\ TRAFFIC, SOILS, VEGETATION, ACID \\ DEPOSITION AND ANY OTHER AIR \\ QUALITY RELATED VALUES}

The proposed project will have no impact on residential or commercial growth or vehicular traffic because the proposed project will be located on the Hanford Site, a Federal Government public exclusion area. 
The following (Jaquish 1989) describes the Hanford Site area soil and vegetation monitoring program and states the results of that program for 1988:

Surface soil and rangeland vegetation samples were collected at a number of locations during 1988, both on and off the Hanford Site. The purpose of sampling was to detect the possible build-up of radionuclides from the deposition of airborne effluents released from Hanford facilities. Samples were collected at nonagricultural, relatively undisturbed sites so that natural deposition and build-up processes would be represented.

An assessment of radionuclide contributions from Hanford operations was made by comparing results from samples collected (1) on Site with those collected off Site, (2) around the Site perimeter with those collected at distant locations, and (3) downwind (primarily east and south of the Site) with those collected from generally upwind and distant locations. In addition, results obtained from each location in 1988 were compared to results obtained from the same location in previous years. Evaluations of 1988 results provided no indication of trends or increases in the concentrations of radionuclides in the offsite environment that could be attributed to Hanford operations.

A detailed description of the results of the above-described study can be found in Chapter 4.5 of the cited publication.

In light of the Pacific Northwest Laboratories (PNL) study results cited above, an increase of emissions on the order of magnitude being discussed $\left(10^{-2}\right)$ indicates that the proposed project will have no measurable effect on soils or vegetation in the area.

\subsection{REFERENCES}

Briesmeister, J. F., Editor, 1986 MCNP - A General Monte Carlo Code for Neutron and Photon Transport, Version 3a, LA-7396-M, Rev.2, Los Alamos National Laboratory, Los Alamos, New Mexico. (Revision of this manual for version $3 \mathrm{~B}$ has also been distributed.)

Bureau of Radiological Health and the Training Institute Environmental Control Administration, 1970, Radiological Health Handbook (Revised Edition), U.S. Department of Health, Education, and Welfare, Rockville, Maryland.

Croff, A. G., 1985 (Update of 1984 document), ORIGEN II, Isotope Generation and Depletion Code (Matrix Exponential Method), CCC 371, Oak Ridge National Laboratory, Oak Ridge, Tennessee.

DOE 1988, Environmental Assessment of SP-100 Ground Engineering System Test Site, Hanford Site, Richland, Washington, DOE/EA-0318, Richl and, Washington. 
Dunning, D. E., R. W. Leggett, M. G. Yalcintas, 1988 (Update of 1980 document), RSIC Computer Code Collection, RADRISK, Estimates of Radiation Doses and Health Effects from Inhalation or Ingestion of Radionuclides, CCC-422, Oak Ridge National Laboratory, Oak Ridge, Tennessee.

EPA, 1984, Background Information Document (Integrated Risk Assessment), Final Rules Radionuclides, Vol. 1, EPA 520/1-022-1, U.S. Environmental Protection Agency, Washington, D.C.

EPA, 1989, National Emission Standards for Hazardous Air Pollutants; Radionuclides; Final Rule and Notice of Reconsideration, U.S. Environmental Protection Agency, Washington, D.C.

ERDA, 1976, A7ternatives for Managing Wastes from Reactors and Post-Fission operation in the LWR Fuel Cycle, Volume 2, ERDA-76-43, U.S. Energy Research and Development Administration, Washington, D.C.

Holtslander, W. J., and J. M. Yaraskovitch, 1981, Tritium Immobilization and Packaging using Metal Hydrides, AECL-7151, Prepared for Atomic Energy of Canada Limited.

IAEA, 1984, Management of Tritium at Nuclear Facilities, Technical Reports Series No. 234, Vienna, Austria.

IAEA, 1981, Hand7ing of Tritium-Bearing Wastes, Technical Reports Series No. 203, Vienna, Austria.

Jaquish, R. E., 1989, Hanford Site Environmental Report for Calendar Year 1988, Prepared for the U.S. Department of Energy by Pacific Northwest Laboratory under Contract DE-AC06-76RLO 1830, Richland, Washington.

Kanada, K., 1975, Control for Radioactive Argon Produced in High Flux Reactor, Osaka, Japan.

Miyasaka, Yasukiko et al., 1977, Modification of JRR-2, JAERI-M 7484, Japan Atomic Energy Research Institute, Tokai-Mura, Naka-qun, Ibaraki-Ken, Japan.

Moore, E. B., 1985, Control Technology for Radioactive Emissions to the Atmosphere at U.S. DOE Facilities (DE-85-011402), Pacific Northwest Laboratories, Richland, Washington.

Oak Ridge National Laboratory, 1987, RSIC Computer Code Collection, CAAC, Code System for Implementation of Atmospheric Dispersion Assessment Required by the Clean Air Act, CCC-476, Oak Ridge National Laboratory, Oak Ridge, Tennessee.

Shor, J. T., 1988, Tritium Effluent Reduction at the Oak Ridge National Laboratory, ORNL/TM-10664, Prepared for the U.S. Department of Energy by Oak Ridge National Laboratory, Oak Ridge, Tennessee. 
Souers et a7., 1984, Electrolytic Gettering of Tritium from Air Journal of Vacuum Science Technology, A2(2), April-June 1984.

Souers et a1., 1985, Tritium Gettering from Air with Hydrogen Uranyl Phosphate UCID-20489, Prepared by the Lawrence Livermore National Laboratory for the U.S. Department of Energy, Livermore, California.

Wieneke et a7., 1988, Tritium Emissions Reduction Facility, MLM-3507(OP), Prepared by the Monsanto Research Corporation for the U.S. Department of Energy, Miamisburg, Ohio. 
DOE/RL-90-14

APPENDIX A

LITERATURE SEARCH

A-1 


\section{NATIONAL TECHNICAL INFORMATION SERVICE (NTIS)}

The NTIS is produced by the National Technical Information Service of the U.S. Department of Commerce. The database consists of government-sponsored research, development, and engineering reports as well as other analyses prepared by government agencies, their contractors, or grantees. The database contains 1.4 million records as of January 1989 covering dates from 1964 to the present and is updated biweekly.

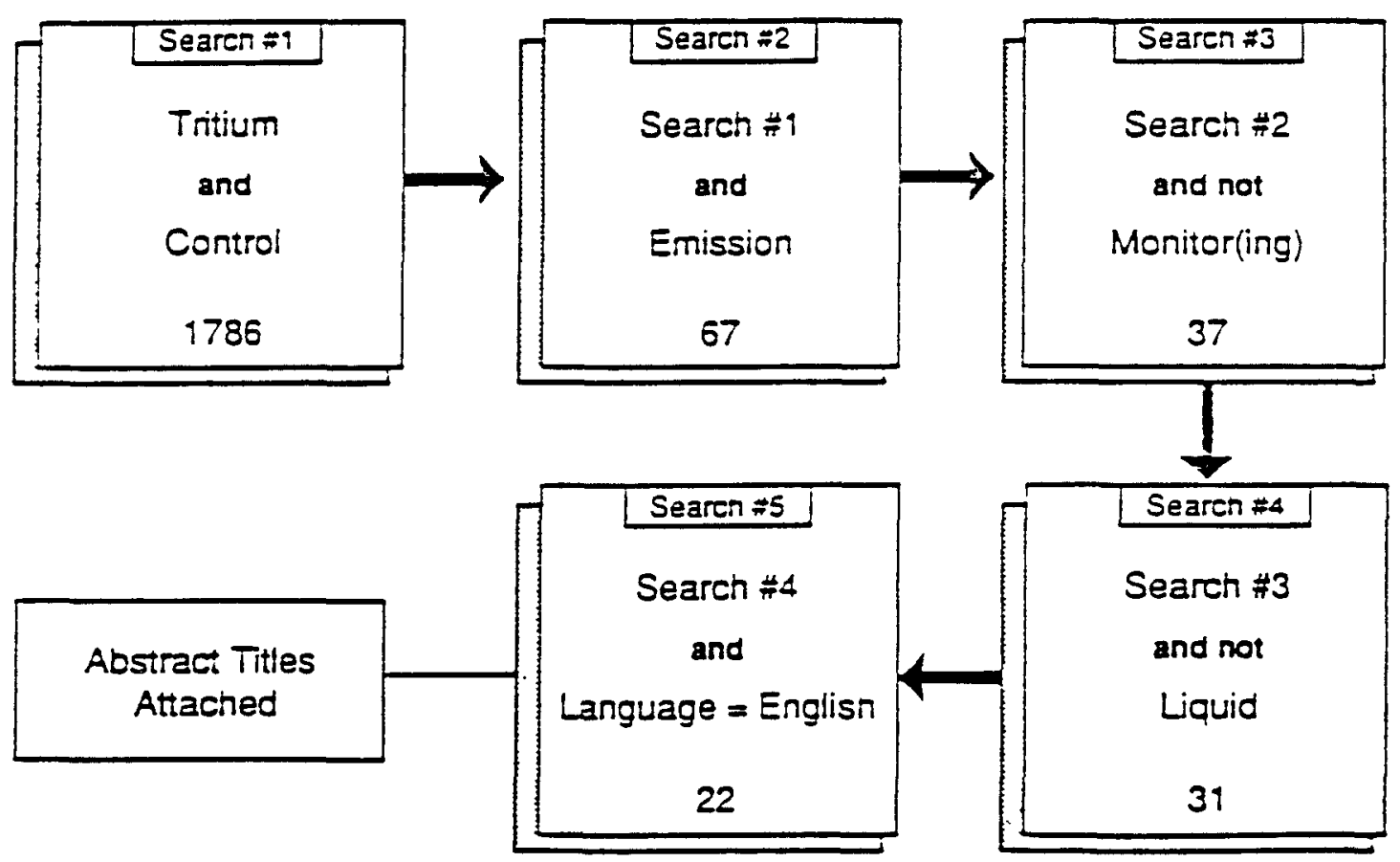


1. Energy and Technology Review

Poggio, A. J.

Lawrence Livermore National Lab., CA.

Sponsor: Department of Energy, Washington, D.C.

oct $8848 \mathrm{p}$

Languages: English.

2. Tritium Effluent Reduction at Oak Ridge National Laboratory

Shor, J. T.

Oak Ridge National Lab., TN.

Sponsor: Department of Energy, Washington, D.C.

Nov $8842 \mathrm{p}$

Languages: English.

3. Environmental Aspects of Fusion Reactors 1985

Casini, G.; Ponti, C.; Rocco, P.

Commission of the European Communities, Ispra (Italy). Joint

Research Centre.

Sponsor: Commission of the European Communities, Luxembourg. $1986111 \mathrm{p}$

Languages: English.

4. Tritium Emissions Reduction Facility

Wieneke, R. E.; Bowser, R. P.; Hedley, W. H.; Kissner, T. J.;

Lamberger, P. H.

Monsanto Research Corp., Miamisburg, $\mathrm{OH}$. Mound.

Sponsor: Department of Energy, Washington, D.C.

$19885 \mathrm{p}$

Languages: English.

Document Type: Conference proceeding

Topical meeting on tritium technology in fission, fusion and isotopic applications, Toronto, Canada, 1 May 1988.

5. International Comparison of Computer Codes for Modelling the Dispersion and Transfer of Tritium Released to the Atmosphere

Russel1, S. B.; Kempe, T. F.; Donnelly, K. J.

Canadian Fusion Fuels Technology Project, Toronto (Ontario). Corp.

May $8552 p$

Languages: English.

6. National Institute of Radiological Sciences: Annual Report, (April 1985-March 1986)

National Inst. of Radiological Sciences, Chiba (Japan). Corp. Source May $86114 \mathrm{p}$

Languages: English. 
7. Nuclear Technology and Forest Dieback

Koenig, L. A.; Penzhorn, R. D.; Schuettelkopf, H.

Oak Ridge National Lab., TN.

Sponsor: Kemforschungszentrum Karlsruhe G.m.b.H. (Germany, F.R.). Inst. fuer Radiochemie.; Department of Energy, Washington, $198533 p$

Languages: English Document Type: Translation

Translation of KfK 3704, March 1984.

8. Control Technology for Radioactive Emissions to the Atmosphere at U.S. Department of Energy Facilities

Moore, E. B.

Batte1le Pacific Northwest Labs., Richland, WA.

Sponsor: Department of Energy, Washington, D.C.

Oct $84 \quad 612$ p

Languages: English.

9. Tritium Autoradiography

Caskey, Jr, G. R.

Du Pont de Nemours (E.I.) and Co., Aiken, SC. Savannah River Lab.

Department of Energy, Washington, D.C.

$198128 \mathrm{p}$

Languages: English Document Type: Conference proceeding

TMS/AIME fall meeting on advanced techniques for the characterization of hydrogen in metals, Louisville, KY, USA, 11 oct.

10. Tritium Accident Containment within a Large Fusion Enclosure: Cost, Benefit, and Risk Considerations

Sherwood, A. E.

Lawrence Livermore National Lab., CA.

Sponsor: Department of Energy, Washington, D.C. $198325 \mathrm{p}$

Languages: English Document Type: Conference proceeding US/Japan

workshop of tritium handling, Los Alamos, NM, USA, 2l Mar 1983.

11. Effects of Coal Combustion and Gasification Upon Lung Structure and

Function.

Quarterly Progress Report

West Virginia Univ. Medical Center, Morgantown.

Sponsor: Department of Energy, Washington, D.C.

12 Dec $805 \mathrm{p}$

Languages: English.

12. Combined Electrolysis Catalytic Exchange (CECE)

Ellis, R. E.; Mills, T. K.; Rogers, M. L.

Mound Facility, Miamisburg, $\mathrm{OH}$.

Sponsor: Department of Energy, Washington, D.C.

30 Sep $8019 \mathrm{p}$

Languages: English. 
13. Tritium Experience at RTNS-II

Logan, C. M.; Davis, J. C.; Gibson, T. A.; Heikkinen, D. W.;

Schumacher, B. J.

California Univ., Livermore. Lawrence Livermore Lab. Corp.

Sponsor: Department of Energy, Washington, D.C.

25 Apr $807 \mathrm{p}$

Languages: English Document Type: Conference proceeding

Tritium technology in fission, fusion, and isotopic applications,

Dayton, OH, USA, 29 Apr 1980.

14. Neutron Personnel Dosimetry Considerations for Fusion Reactors

Barton, T. P.; Easterly, C. E.

Oak Ridge National Lab., TN.

Sponsor: Department of Energy.

Jul $7963 \mathrm{p}$

Languages: English

Thesis. Submitted by T. P. Barton to Purdue Univ., Lafayette, IN.

15. Mixing Rules for and Effects of Other Hydrogen Isotopes and of Isotopic

Swamping on Tritium Recovery and Loss to Biosphere from Fusion Reactors

Pendergrass, J.H.

Los Alamos Scientific Lab., NM.

Sponsor: Department of Energy.

$197817 \mathrm{p}$

Languages: English Document Type: Conference proceeding

Meeting on the technology of controlled thermonuclear fusion, Santa Fe, NM, USA, 9 May 1978.

16. Gaseous Fission Product Release During Storage at Various Temperatures for HTGR-Type Fuels

Fitzgerald, C. L.; Shannon, R. J.; Vaughen, V. C. A.

Oak, Ridge National Lab., TN.

Sponsor: Department of Energy.

Jul $78 \quad 44 p$

Languages: English.

17. Tritium Waste Control: Apri1--September 1977

Mound Lab., Miamisburg, Ohio.

Sponsor: Department of Energy.

9 Jan $7844 \mathrm{p}$.

18. Tritium Storage Development. Progress Report No. 9, July--September 1976

Brookhaven National Lab., Upton, N.Y.

Sponsor: Energy Research and Development Administration.

$197625 \mathrm{p}$.

19. Construction and Operation of Barnwell Nuclear Fuel Plant.

Draft Supplement No. 1 to the Final Environmental Statement

Nuclear Regulatory Commission, Washington, D.C. Office of Nuclear Material Safety and Safeguards.

Jun $7673 \mathrm{p}$. 
20. Tritium Control in a Mirror-Fusion Central Power Station Galloway, T. R.

California Univ., Livermore. Lawrence Livermore Lab. Corp. Sponsor: Energy Research and Development Administration. 25 Aug $7613 \mathrm{p}$

Document Type: Conference proceeding

Topical meeting on the technology of controlled nuclear fusion, Richland, Washington, United States of America (USA), 21 Sep.

21. Apparatus for the Reduction of Tritium Emissions into the Atmosphere Dube, C. M.; Coffin, D. 0.; Stol1, R. D. Los Alamos Scientific Lab., N. Mex. Jun $734 \mathrm{p}$.

22. An Apparatus for the Reduction of Tritium Emissions into the Atmosphere (Informal rept.)

Dube, C. M.; Coffin, D. 0.; Sto11, R. D. Los Alamos Scientific Lab., N. Mex. Jun $737 \mathrm{p}$. 


\section{DOE ENERGY}

The DOE ENERGY is a multidisciplinary file containing worldwide references to basic and applied scientific and technical research literature. The information is collected for use by government managers, researchers at the National Laboratories, and other research efforts sponsored by the Department of Energy and to transfer the results of this research to the public. The database contains 883,768 records as of January 1989 covering dates from 1983 to the present and is updated biweek $7 y$.

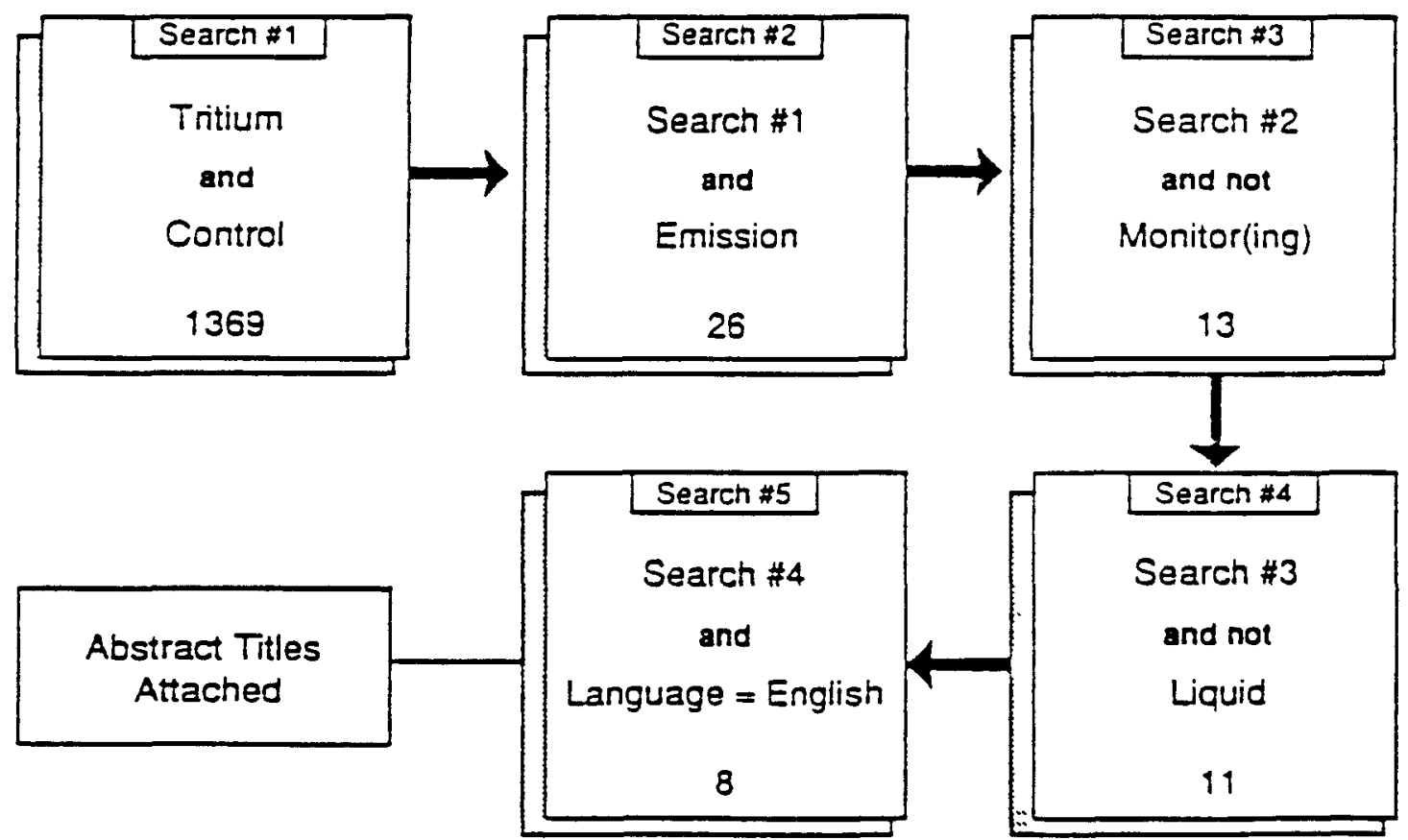


1. Radiolabelled D/sub 2/agonists as prolactinoma imaging agents:

Progress report for period February 1, 1987-January 31, 1988

otto, CA.

Michigan Univ., Dearborn (USA)

7 Nov 19878 p.

2. Measurement of alpha and beta activity in water and sludge samples. The determination of radon-222 and radium-226. The determination of uranium (including general x-ray fluorescent spectrometric analysis). 1985-1986 Department of the Environment, London (UK)

Publ: H.M. Stationery Office, London, England, 1986. $76 \mathrm{p}$.

3. Proceedings of the 11 th symposium on fusion engineering Bartlit, J.R.; Anderson, J.L.

Materials Science and Technology Div., MS C348, Los Alamos National Lab., Los Alamos, NM 87545

11. symposium on engineering problems in fusion research Austin, TX, USA 18 Nov 1985

Pub7: IEEE Service Center, Piscataway, NJ,

1986. 627-630 p.

4. Uptake of radiolabeled ions in normal and ischemia-damaged brain Diene1, G.A.; Pulsine11i, W.A.

Cornell Univ. Medical College, New York, NY

Ann. Neurol. (United States) $\vee 5$.

May 1986. 465-472 p.

5. The management of gaseous wastes from reprocessing containing volatile

fission products

Progress in nuclear energy: Volume 13

Plumb, G.R.; Williams, M.M.R.; McCormick, N.J.

British Nuclear Fuels Ltd., Risley, Warrington, Cheshire WA3 6AS

Pub1: Pergamon Press, Elmsford, NY,

1984. 63-74 p.

6. Control technology for radioactive emissions to the atmosphere at U.S. Department of Energy facilities

Moore, E.B.

Pacific Northwest Lab., Richland, WA (USA)

Oct 1984. $612 \mathrm{p}$.

7. Management of gaseous wastes from reprocessing containing volatile fission products

Plumb, G.R. (British Nuclear Fuels Ltd., Risley) Prog. Nucl. Energy (United Kingdom) $\vee 13: 1.1984 .63-74 \mathrm{p}$.

8. Biliary excretion and enterohepatic circulation of /sup $3 / \mathrm{H}$-nitropyrene Inhalation Toxicology Research Institute. Annual report, October 1 , 1981-September 30, 1982

Medinsky, M.A.; Shelton, H.; Snipes, M.B.; Marshal1, T.C.; Martinez, B.S. (eds.) Dec 1982. 253-255 p. 


\section{POLLUTION ABSTRACTS}

POLLUTION ABSTRACTS is a leading resource to environmentally related technical literature on pollution, its sources, and its control. References in Pollution Abstracts are drawn from approximately 2,500 primary sources from around the world, including books, conference papers/proceedings, periodicals, research papers, and technical reports. As of October 1988 the database consisted of 240,000 records covering the period 1970 to the present and updated bimonthly.

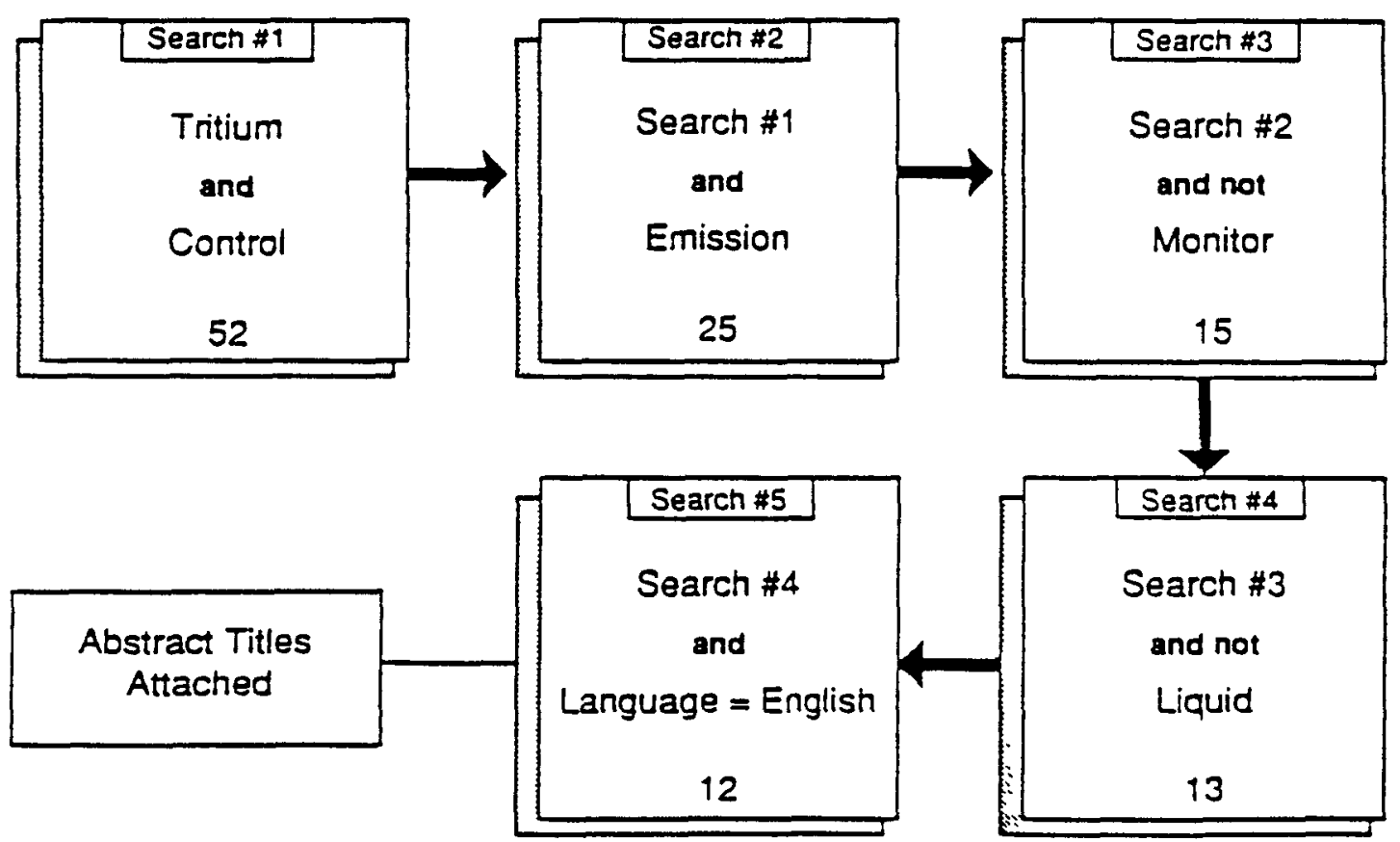


1. Pumping of corrosive or hazardous gases with turbomolecular and oil-filled rotary vane backing pumps

Fischer, K.; Henning, J.; Abbel, K.; Lotz, H.

A. Pfeiffer Vakuumtechn. Wetzlar GmbH, Emmeliusst. 33, D-6334 Asslar, FRG Biennial Conf. Vacuum Group of Inst. Phys. Chester, UK 29-31 Mar 1982 VACUUM VOL. 32 , NO. 10-11, pp. 619-621, Publ. Yr: 1982.

2. New turbomolecular pumps for application with radioactive gases, e.g. tritium

Abbel, K.; Henning, J.; Lotz, H.

Balzers: Arthur Pfeiffer Vakuumtechn. Wetzlar GmbH, D-6334 Asslar, FRG Biennial Conf. Vacuum Group of Inst. Phys. Chester, UK 29-31 Mar 1982 VACUUM VOL. 32, NO. 10-11, pp. 623-625, Publ. Yr: 1982

SUMMARY LANGUAGE- ENGLISH.

3. Mechanical booster for pumping radioactive and other dangerous gases Budgen, L.J.

Edwards High Vacuum, Manor Royal, Crawley, Sussex, UK Biennial Conf. Vacuum Group of Inst. Phys. Chester, UK 29-31 Mar 1982

VACUUM VOL. 32, NO. 10-11, pp. 627-629,

Pub1. Yr: 1982

SUMMARY LANGUAGE - ENGLISH.

4. Distribution of Tritium and Carbon-14 Compounds in Aqueous and Organic Phases of Various Structures of Aquatic and Terrestrial Food Chains

Clausen, E.; Leister, W.; Nuernberger, E.; Kistner, G.N.

Inst. Strahlenhygiene, BGA, Ingolstaedter Landstrasse, D-8042,

Neuherberg, FRG

IN "PROGRESS REPT. PROGRAM - RADIATION PROTECT. 1981 pp. 258-260, Publ. Yr: 1981

OFFICE OFFICIAL PUBLIC. EUROP. COMMUN., 5 RUE DU COMMERCE,

L-2985 LUXEMBOURG

SUMMARY LANGUAGE - ENGLISH; Abstr. Onty.

5. Tritium transport at nuclear power stations.

Caruthers, G. F.; Bradshaw, R. W.

Combustion Engineering, Inc., 1000 Prospect Hill Rd., Windsor, CT 06095

American Nuclear Society: 25th annual meeting Atlanta, Georgia

Jun $3-7,1979$

American Nuclear Society

AMERICAN NUCLEAR SOCIETY. TRANSACTIONS 32, 653-654,

Publ. Yr: 1979.

6. Environmental aspects of the fusion materials resource cycle.

Long, L.; Will ingham, C. E.; Young, J. K.

BMI, Pacific Northwest Labs, P.0. Box 999, Richland, WA 99352

American Nuclear Society: 25th annual meeting Atlanta, Georgia

Jun 3-7, 1979

American Nuclear Society

AMERICAN NUCLEAR SOCIETY. TRANSACTIONS 32, 122, Publ. Yr: 1979. 
7. Biological implications of radionuclides released from nuclear industries: (Symposium report).

Anonymous.

IAEA international symposium Vienna, Austria Mar 26-30, 1979

INTERNATIONAL ATOMIC ENERGY AGENCY. BULLETIN 21(4), 51-53,

Publ. Yr: Aug 1979.

8. Separation of tritium from gaseous and aqueous effluent systems.

Kobisk, E. H.

Oak Ridge National Lab., Bldg. 3037, Room 208, P.0. Box X,

Oak Ridge, TN 73830

Seminar on radioactive effluents from nuclear fuel reprocessing $p l a n t s$

Karlsruhe, FRG Nov. 22-25, 1977

Radioactive effluents from nuclear fuel reprocessing plants: Seminar proceedings Publ. Yr: 1978 pp. 461-496

Publ: Luxembourg Commission of the European Communities.

9. Reprocessing off-gas treatment research in Belgium.

Baetsle, L. H.; Broothaerts, J.

CEN/SCK, Boeretang 200, 2400 Mol, Bel.

Seminar on radioactive effluents from nuclear fuel reprocessing plants

Karlsruhe, FRG Nov. 22-25, 1977

Radioactive effluents from nuclear fuel reprocessing plants: Seminar proceedings

Pub7. Yr: 1978 pp. 421-445.

10. The discharge to atmosphere of radionuclides from reprocessing plants and the associated radiation exposure of the public.

Bryant, P. M.

National Radiological Protection Board, Harwe11, Didcot, Oxfordshire 0x11 ORQ, Eng.

Seminar on radioactive effluents from nuclear fuel reprocessing $p l a n t s$

Karlsruhe, FRG Nov. 22-25, 1977

Radioactive effluents from nuclear fuel reprocessing plants: Seminar proceedings Publ. Yr: 1978 pp. 247-272

Pub7: Luxembourg Commission of the European Communities.

11. Tritium removal from air streams by catalytic oxidation and water adsorption.

SHERWOOD, A.E.

Univ. of California, Lawrence Livermore Lab., P.0. Box 808, Livermore, CA 94550

American Nuclear Society: 1976 International Meeting. In American Nuclear Society. Transactions, 24: 498, 1976

Publ. Yr: 1976.

12. Radiological aspects of environmental tritium.

WILCOX, W.H.

Oak Ridge National Lab., Environmental Sciences Div.,

Oak Ridge, TN 37830

Nuclear Safety, 17(2): 216-223, Mar.-Apr. 1976

Publ. Yr: 1976 


\section{NATIONAL TECHNICAL INFORMATION SERVICE (NITS)}

The NTIS is produced by the National Technical Information Service of the U.S. Department of Commerce. The database consists of government-sponsored research, development, and engineering reports as well as other analyses prepared by government agencies, their contractors, or grantees. The database contains 1.4 million records as of January 1989 covering dates from 1964 to the present and is updated biweekly.

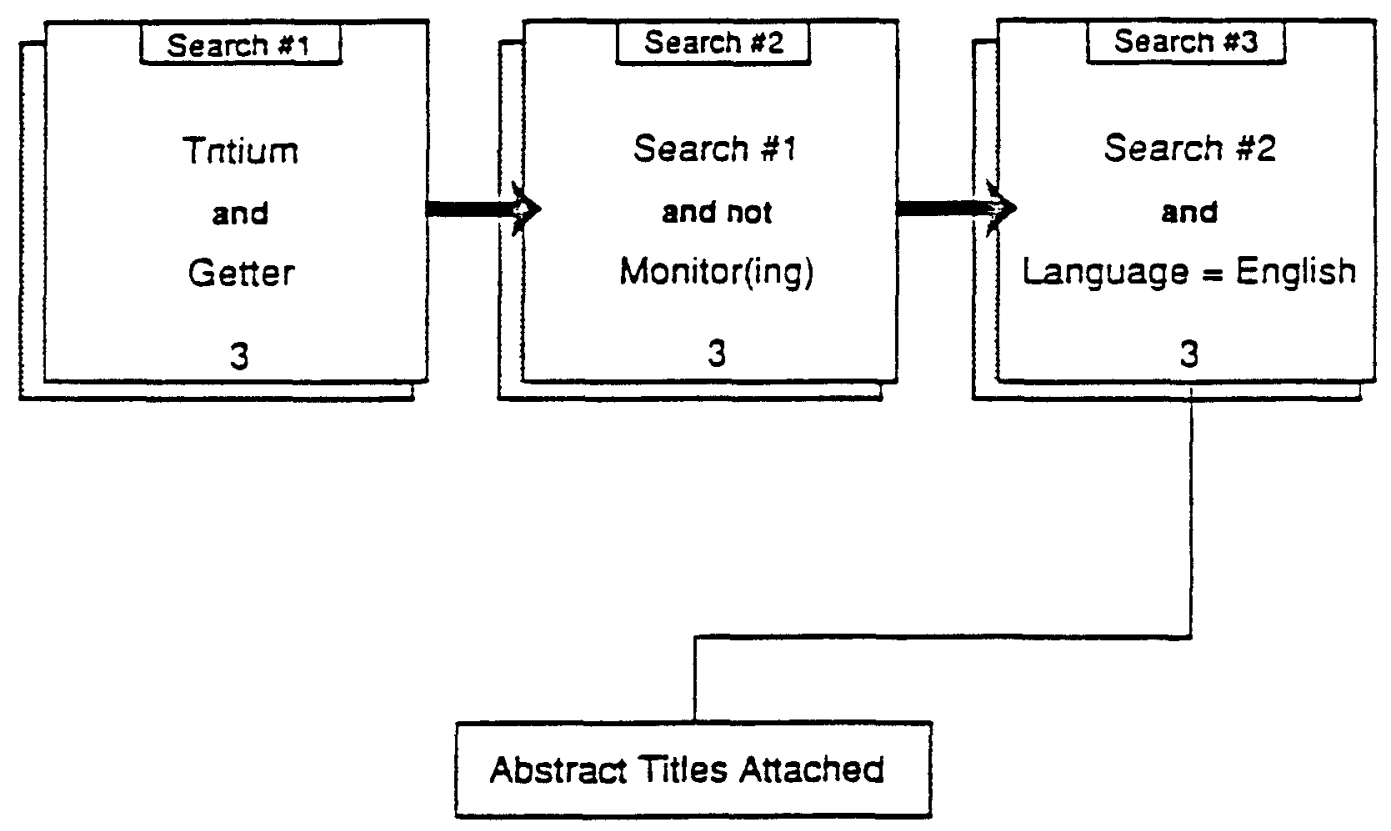


1. Tritium Gettering from Air with Hydrogen Uranyl Phosphate Souers, P. C.; Uribe, F. S.; Stevens, C. G.; Tsugawa, T. T. Lawrence Livermore National Lab., CA.

Sponsor: Department of Energy, Washington, D.C. Aug $85 \quad 17 p$

Languages: English

Country of Publication: United States.

2. 1,4-Diphenylbutadiyne as a Potential Tritium Getter

Miller, H. H.; Bisse11, E. E.; Tsugawa, R. T.; Souers, P. C. Lawrence Livermore National Lab., CA.

Sponsor: Department of Energy, Washington, D.C. 1 Oct $8019 \mathrm{p}$

Languages: English

Document Type: Conference proceeding Journal

16. DOE nuclear air cleaning conference, San Diego, CA, USA, 20 0ct 1980.

Country of Publication: United States.

3. Considerations on a Tritium Reprocessing System Utilizing Solid Tritium Getters in a Lithium Cooled Thermonuclear Reactor Yakura, J. S.

California Univ., Los Angeles. Dept. of Energy and Kinetics. Mar $77109 \mathrm{p}$. 


\section{DOE ENERGY}

The DOE ENERGY is a multidisciplinary file containing worldwide references to basic and applied scientific and technical research literature. The information is collected for use by government managers, researchers at the National Laboratories, and other research efforts sponsored by the Department of Energy and to transfer the results of this research to the public. The database contains 883,768 records as of January 1989 covering dates from 1983 to the present and is updated biweekly.

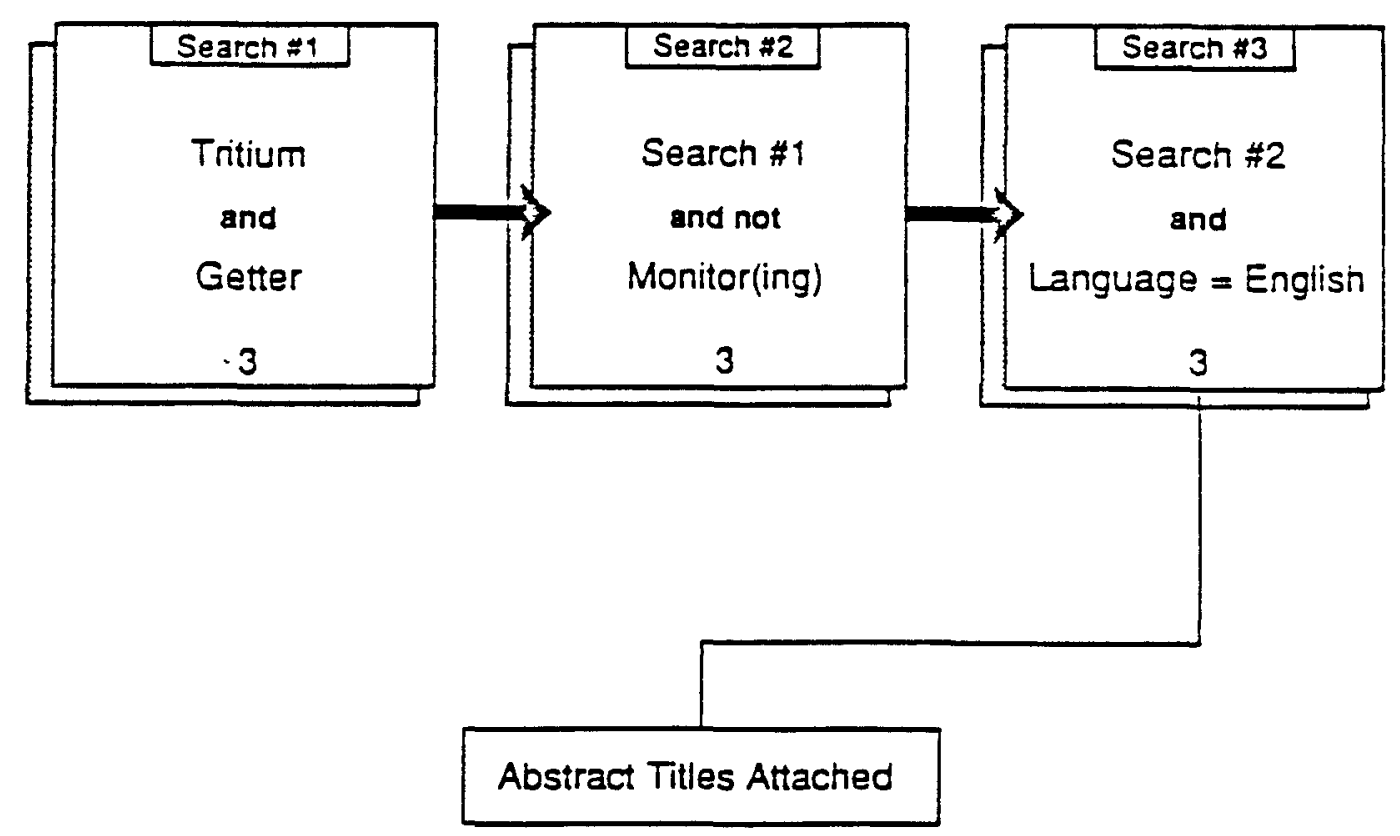


1. A zirconium-cobalt compound as the material for a reversible tritium getter Nagasaki, T.; Konishi, S.; Katsuta, H.; Naruse, Y. Japan Atomic Energy Research Inst., Tokai-mura, Ibaraki-ken, 319-11 Fusion Technor. (United States) v 9:3. May 1986. 506-509 v p. Coden: FUSTE Document Type: Journal Article Language: English.

2. Dissolved nitrogen in liquid lithium - a problem in fusion reactor chemistry

Liquid metal engineering and technology. 3 Vols. Proceedings of the 3 . international conference held in 0xford on 9-13 April 1984. Vol. 2 Hubberstey, $P$.

Nottingham Univ., UK. Dept. of Chemistry

British Nuclear Energy Society, London; International Atomic Energy Agency, Vienna (Austria). International Working Group on Fast Reactors; American Nuclear Society, La Grange Park, IL; European Nuclear Society, Petit-Lancy (Switzerland)

3. meeting on liquid metal in energy applications 0xford, UK 9 Apr 1984 Publ: British Nuclear Energy Society, London, England, 1984. 85-92 p. Country of Publication: United Kingdom.

3. Tritium gettering from air with hydrogen uranyl phosphate Souers, P.C.; Uribe, F.S.; Stevens, C.G.; Tsugawa, T.T. Lawrence Livermore National Lab., CA (USA)

Aug 1985. $17 \mathrm{p}$.

Document Type: Report

Language: English

Atomindex input). TIC (Technical Information Center)

Country of Publication: United States. 


\section{POLLUTION ABSTRACTS}

POLLUTION ABSTRACTS is a leading resource to environmentally related technical Titerature on pollution, its sources, and its control. References in Pollution Abstracts are, drawn from approximately 2,500 primary sources from around the world, including books, conference papers/proceedings, periodicals, research papers, and technical reports. As of 0ctober 1988 the database consisted of 240,000 records covering the period 1970 to the present and updated bimonthly.

\begin{tabular}{c} 
Search \#1 \\
Tritium \\
and \\
Getter \\
0 \\
\hline
\end{tabular}




\section{NATIONAL TECHNICAL INFORMATION SERVICE (NTIS)}

The NTIS is produced by the National Technical Information Service of the U.S. Department of Commerce. The database consists of government-sponsored research, development, and engineering reports as well as other analyses prepared by govermnent agencies, their contractors, or grantees. The database contains 1.4 million records as of January 1989 covering dates from 1964 to the present and is updated biweekly.

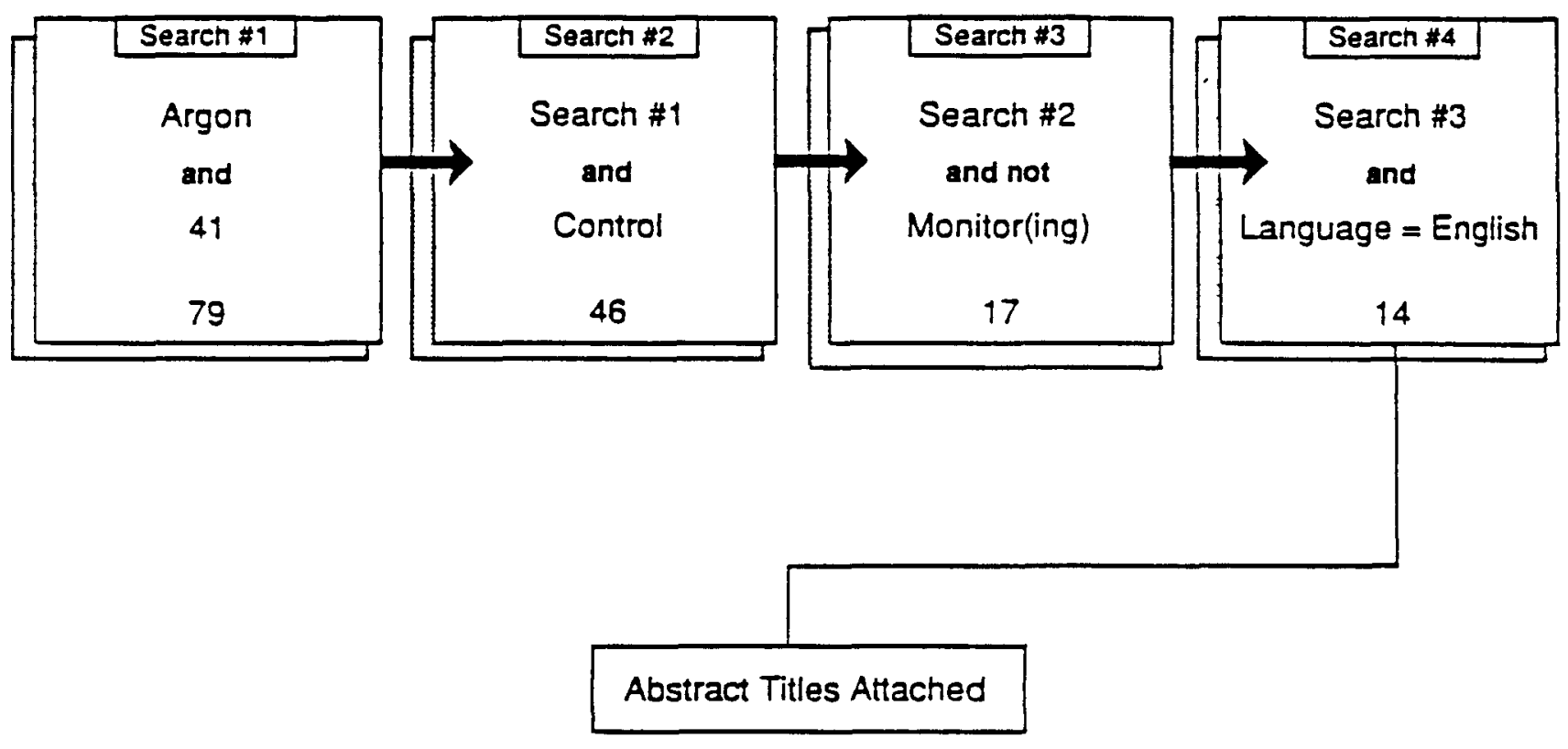


1. Improved Estimates of External gamma Dose Rates in the Environs of Hinkley Point Power Station

Macdonald, H. F.; Thompson, I. M. G.; Foster, P. M.; Robins, A. G. Central Electricity Generating Board, Berkeley (England). Berkeley Nuclear Labs.

Jul $8884 \mathrm{p}$

Languages: English

Country of Publication: United Kingdom.

2. Nuclear Industries Reactor and Fuels Production Facilities.

1984 Effluent Release Report

Rokkan, D. J.

UNC Nuclear Industries, Inc., Richland, WA.

Sponsor: Department of Energy, Washington, D.C.

15 Mar $8527 \mathrm{p}$

Languages: English

Country of Publication: United States.

3. 1985 Annual Site Environmental Report for Argonne National Laboratory Golchert, N. W.; Duffy, T. L.; Sedlet, J.

Argonne National Lab., IL.

Sponsor: Department of Energy, Washington, D.C.

Mar $86103 \mathrm{p}$

Languages: English

Country of Publication: United States.

4. Radiological Effect on SRP (Savannah River Plant) Operations - 1984 Marter, W. L.

Du Pont de Nemours (E.I.) and Co., Aiken, SC. Savannah River Lab. Corp. Sponsor: Department of Energy, Washington, D.C.

12 Jun $8527 \mathrm{p}$

Languages: English

Country of Pubiication: United States.

5. Control Technology for Radioactive Emissions to the Atmosphere at U.S. Department of Energy Facilities: The Los Alamos Meson Physics Facility.

Addendum 1

Moore, E. B.; Fullam, H. T.

Battelle Pacific Northwest Labs., Richland, WA.

Sponsor: Department of Energy, Washington, D.C.

Mar $8522 \mathrm{p}$

Languages: English

Country of Pubiication: United States.

6. Airborne Radioactive Effluent Study at the Savannah River Plant

Blanchard, R. L.; Broadway, J. A.; Sensintaffar, E. L.; Kirk, W. P.;

Kahn, B.

Eastern Environmental Radiation Facility, Montgomery, AL.

JuT $84144 p$

Languages: English

Country of Pubiication: United States. 
7. Radiological Effect of SRP (Savannah River Plant) Operations, 1979 Marter, W. L.

Du Pont de Nemours (E.I.) and Co., Aiken, SC. Savannah River Lab. Corp. Sponsor: Department of Energy, Washington, D.C.

16 May $8014 \mathrm{p}$

Languages: English

Country of Publication: United States.

8. Radiation Exposure of the UK Population from Airborne Effluents

Discharged from Civil Nuclear Installations in the UK in 1978

Kelly, G. N.; Jones, J. A.; Broomfield, M.

National Radiological Protection Board, Harwell (England). Corp.

Dec $8192 \mathrm{p}$

Languages: English

Country of Publication: United Kingdom.

9. Solvent-refined-coal (SRC) Process. Quarterly Technical Progress Report, July 1980-September 1980

Pittsburg and Midway Coal Mining Co., Englewood, Co. Corp.

Sponsor: Department of Energy, Washington, D.C.

Jul $81219 \mathrm{p}$

Languages: English.

10. Concentric Cylinder Set Model for Estimating Dose from Gamma-Emitting Cloud (Technical rept.)

Arras, J. M.

Armed Forces Radiobiology Research Inst., Bethesda, MD. Corp.

Mar $8130 \mathrm{p}$

Languages: English

Country of Publication: United States.

11. Modification of JRR-2

Miyasaka, Y.

Japan Atomic Energy Research Inst., Tokyo.

Jan $7825 p$

Languages: English

Country of Publication: Japan.

12. Adpic: A Three-Dimensional Transport-Diffusion Model for the Dispersal of Atmospheric Pollutants and Its Validation Against Regional Tracer Studies Lange, $R$.

California Univ., Livermore Lawrence Livermore Lab. Corp. May $7540 \mathrm{p}$

Document Type: Conference proceeding. 
13. United Nuclear Industries, Inc., Reactor and Fuel Production Facilities 1973

Environmental Release Report

Dabrowski, T. E.

United Nuclear Industries, Inc., Richland, Wash.

15 Mar $7414 \mathrm{p}$.

14. Reduction of 41 Ar Environmental Releases at Research Reactors (Technical note) Verrelli, D. M.; Carter, R. E.; Slaback, Jr, L. A. Armed Forces Radiobiology Research Inst Bethesda Md Corp. Aug $7314 \mathrm{p}$. 


\section{DOE ENERGY}

The DOE ENERGY is a multidisciplinary file containing worldwide references to basic and applied scientific and technical research literature. The information is collected for use by government managers, researchers at the National Laboratories, and other research efforts sponsored by the Department of Energy and to transfer the results of this research to the public. The database contains 883,768 records as of January 1989 covering dates from 1983 to the present and is updated biweekly.

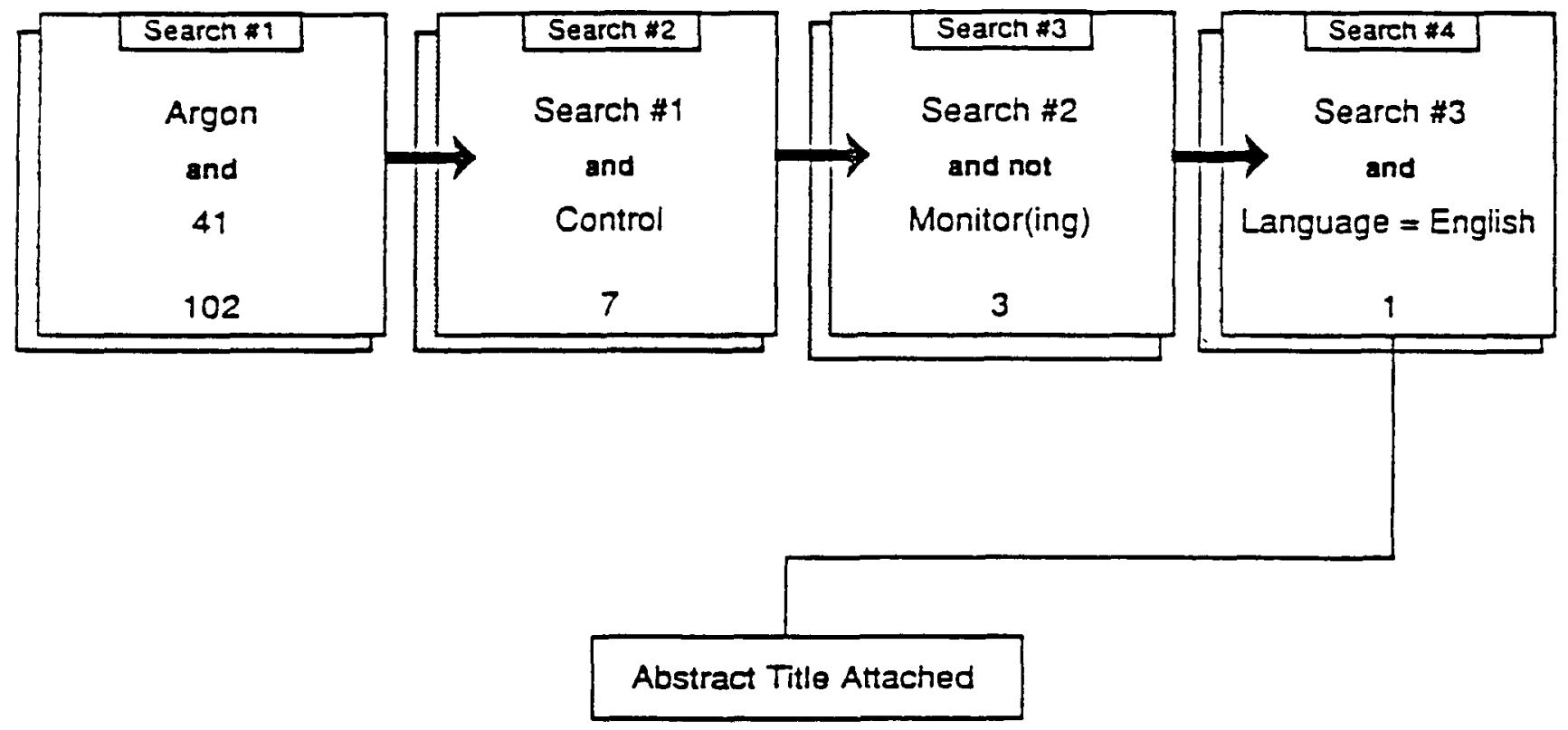


DOE/RL-90-14

1. Control technology for radioactive emissions to the atmosphere at U.S. Department of Energy Facilities: the Los Alamos Meson Physics Facility.

Addendum 1

Moore, E.B.; Fullam, H.T.

Pacific Northwest Labs., Richland, WA (USA)

Mar 1985. $22 \mathrm{p}$.

Document Type: Report; Numerical data

Language: Engl ish

Country of Publication: United States 


\section{POLLUTION ABSTRACTS}

POLLUTION ABSTRACTS is a leading resource to environmentally related technical literature on pollution, its sources, and its control. References in Pollution Abstracts are drawn from approximately 2,500 primary sources from around the world, including books, conference papers/proceedings, periodicals, research papers, and technical reports. As of 0ctober 1988 the database consisted of 240,000 records covering the period 1970 to the present and updated bimonthly.

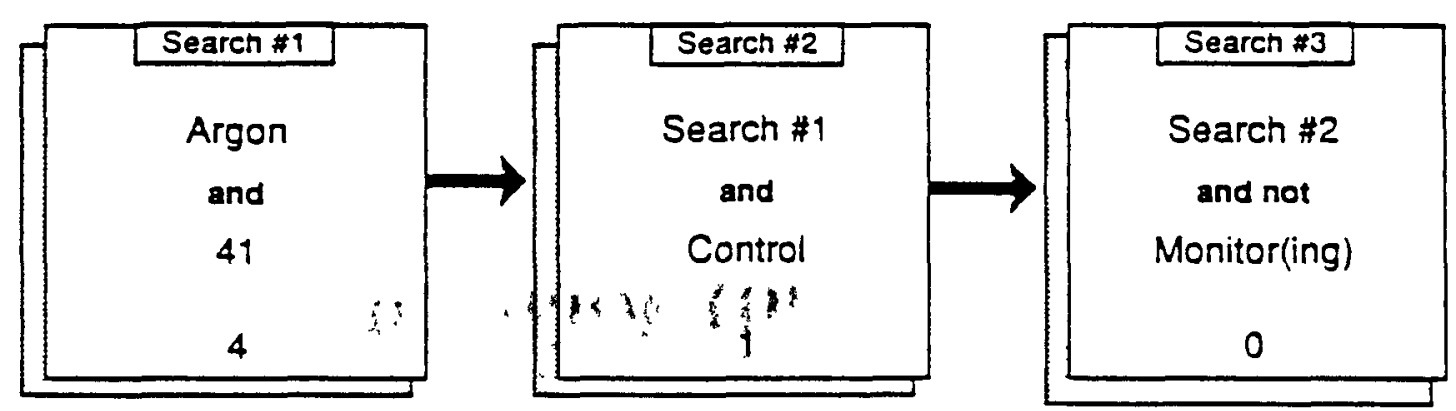


DOE/RL - 90-14

This page intentionally left blank.

NOT MIR,ROFII'.1

....n. 
DOE/RL $-90-14$

\section{APPENDIX B}

DERIVED CONCENTRATION GUIDE (DCG) 


\section{APPENDIX B}

\section{DERIVED CONCENTRATION GUIDE (DCG)}

The DCG values are derived for the purpose of relating concentration of radionuclides in the environment to a human dose. When a standard man is exposed continuously for 1 yr to air concentrations at one times the DCG value, he will receive an effective committed dose equivalent of $100 \mathrm{mrem}$ to the whole body or other limiting dose to an organ. When more than one radionuclide is involved in the exposure, the fractional relationship of the concentration of each radionuclide to its respective DCG value must be summed to determine the total dose from the radionuclide mix. The DCG values relate to a 100-mrem dose only when applied at the point of exposure to humans. For the SP-100 facility, these values are specified at the release point for exhaust from containment (stack). The chronic dose to a resident is lower because of meteorological dispersion.

The DCGs for the critical radionuclides to be emitted by the SP-100 GES are as follows:

$\begin{array}{cc}\text { Radionuclide } & \text { DCG } \\ { }^{41 \mathrm{Ar}} & 1.0 \mathrm{E}-08 \mathrm{uCi} / \mathrm{ml} \text { of air } \\ { }^{14} \mathrm{C} & 5.0 \mathrm{E}-07 \mathrm{uCi} / \mathrm{ml} \text { of air } \\ { }^{3} \mathrm{H} & 1.0 \mathrm{E}-07 \mathrm{uCi} / \mathrm{ml} \text { of air }\end{array}$


DOE/RL $-90-14$

\section{DISTRIBUTION}

Number of copies

\section{ONSITE}

West inghouse Hanford Company
J. A. Bates
$\mathrm{H} 4-50$
E. J. Bitten
L4 - 76
M. T. Jansky
H4 -57
R. E. Lerch
B2 -35
J. J. Luke (8)
$\mathrm{H} 4-57$
M. K. Mahaffey
L4 -73
R. C. Nichols
B3 -02
G. L. Smith
L4 - 75
Environmental Division
Media Center (1)
DOE/RL Public Reading Room (2)
$\mathrm{H} 4-22$
PNL Technical Files (1)
A $1-65$
$\mathrm{K} 1-11$
Publications Services (11)
A2 -24
Central Files ?
L8- 04 
DOE/RL $-90-14$

This page intentionally left blank.

\section{"MP) NOT MIR,RDFII.}

$$
\text { " }
$$

